\title{
HYDROGEOLOGY OF THE SPLIT ROCK CREEK AQUIFER WITH EMPHASIS ON CALIBRATION OF A NUMERICAL FLOW MODEL, SOUTHEAST MINNEHAHA COUNTY, SOUTH DAKOTA
}

By LARRY D. PUTNAM

U.S. GEOLOGICAL SURVEY

Water-Resources Investigations Report 97-4102

Prepared in cooperation with the

CITY OF SIOUX FALLS and

EAST DAKOTA WATER DEVELOPMENT DISTRICT

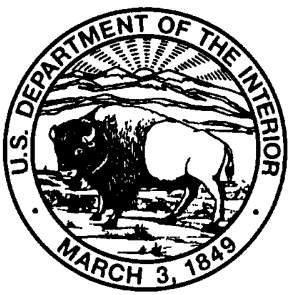




\title{
U.S. DEPARTMENT OF THE INTERIOR BRUCE BABBITT, Secretary
}

\author{
U.S. GEOLOGICAL SURVEY
}

Thomas J. Casadevall, Acting Director

The use of firm, trade, and brand names in this report is for identification purposes only and does not constitute endorsement by the U.S. Geological Survey.

For additional information write to:

Copies of this report can be purchased from:

District Chief

U.S. Geological Survey

1608 Mt. View Road

Rapid City, SD 57702
U.S. Geological Survey

Branch of Information Services

Box 25286

Denver, CO 80225-0286 


\section{CONTENTS}

Abstract

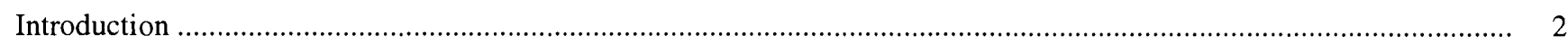

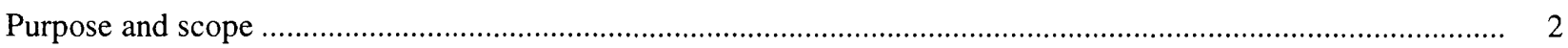

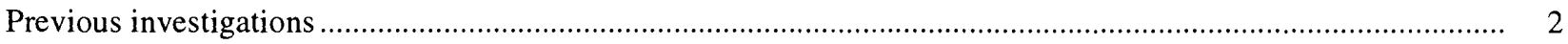

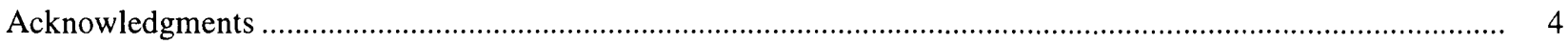

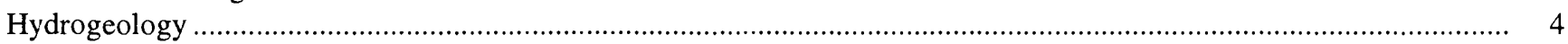

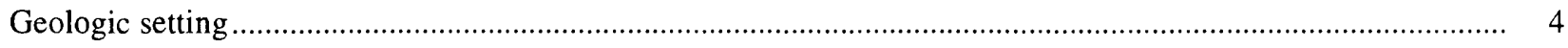

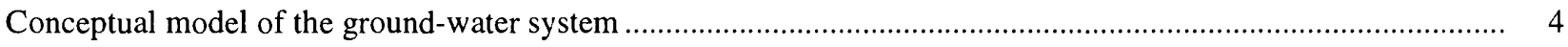

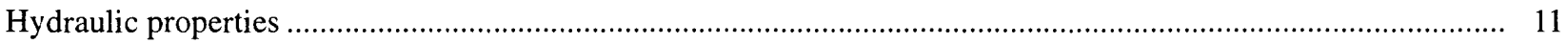

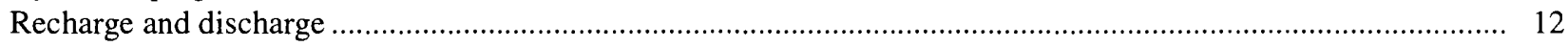

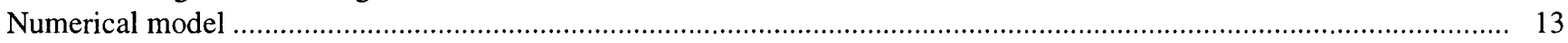

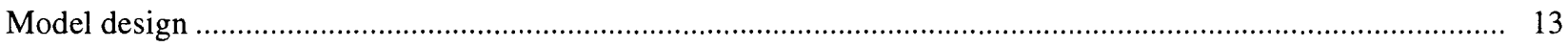

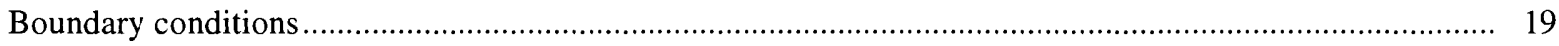

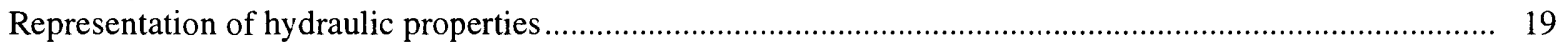

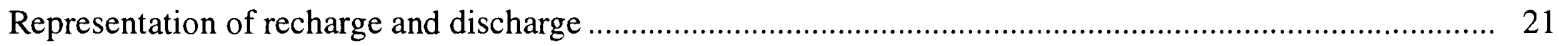

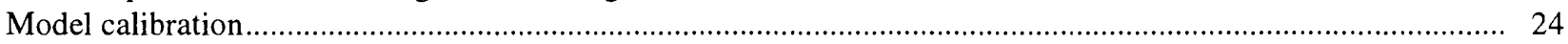

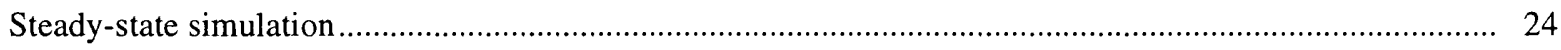

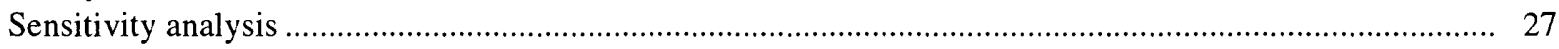

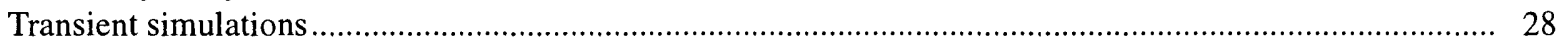

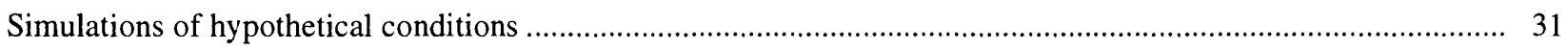

Simulation of average conditions with increased pumping ......................................................... 31

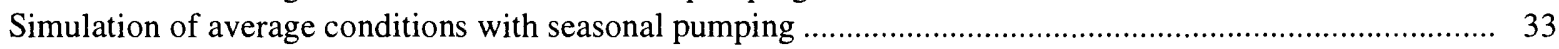

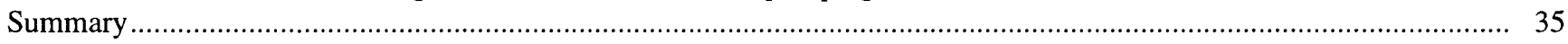

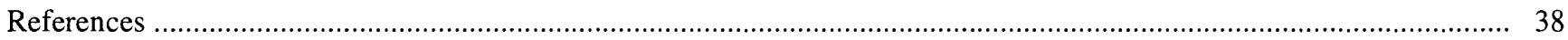

\section{ILLUSTRATIONS}

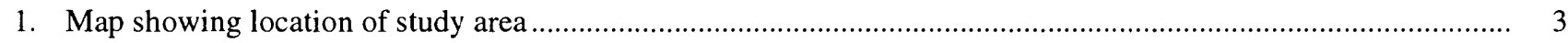

2. Map showing configuration of Sioux Quartzite Precambrian rock surface ....................................................... 5

3. Map showing extent and thickness of Split Rock Creek aquifer ..................................................................

4. Hydrogeologic section A-A' showing Pipestone Creek, Brandon, Big Sioux, Split Rock Creek,
and Sioux Quartzite aquifers........................................................................................................

5. Map showing extent of parts of Big Sioux, Brandon, Pipestone Creek, and Beaver Creek aquifers....................... 8

6. Map showing average potentiometric surface in Split Rock Creek aquifer and surrounding

7. Hydrograph showing comparison of hydraulic head in Split Rock Creek aquifer

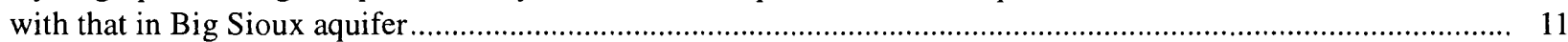

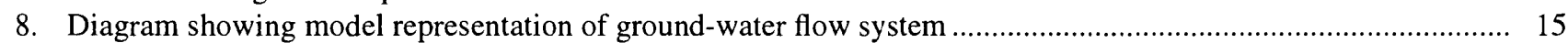

9. Map showing finite-difference grid and boundary conditions for model layer 1 ............................................. 16

10. Map showing finite-difference grid and boundary conditions for model layer 2 ......................................... 17

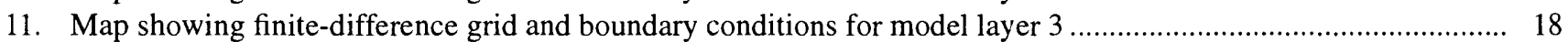

12. Map showing ranges of transmissivity and locations of aquifer tests in Split Rock Creek aquifer ........................ 20

13. Map showing model grid blocks where vertical conductance between model layer 1

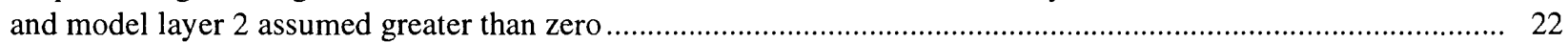

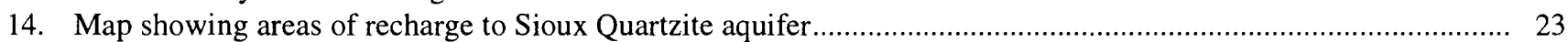

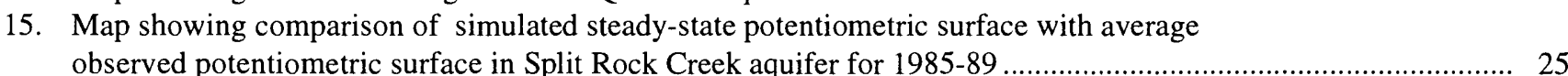




\section{ILLUSTRATIONS-Continued}

16. Hydrographs showing comparison of simulated and observed hydraulic head in Split Rock

Creek, Big Sioux, and Sioux Quartzite aquifers for transient simulations, 1990-93

17. Map showing drawdown in Split Rock Creek aquifer at the end of 3 years of transient quarterly simulation of hypothetical average conditions with increased pumping of 4 cubic feet per second.

18. Map showing drawdown in Split Rock Creek aquifer at the end of the third quarter of the third year of transient quarterly simulations of hypothetical average conditions with additional pumping of 10 cubic feet per second during the third quarter....

19. Graphs showing comparison of mean drawdown in the main body of the Split Rock

Creek aquifer with transient quarterly simulation of hypothetical average conditions and additional pumping of 10 cubic feet per second during the summer quarter, with increased and decreased Sioux Quartzite transmissivity and fractured siltstone vertical conductance

\section{TABLES}

1. Seasonal recharge rate

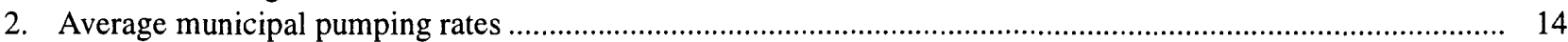

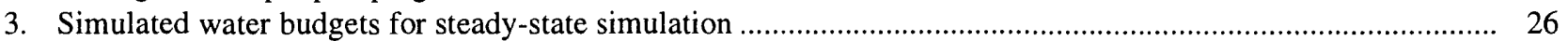

4. Summary of sensitivity analysis results for the steady-state model ............................................................. 27

5. Comparison between simulated and observed hydraulic heads in the Split Rock Creek aquifer......................... 28

6. Split Rock Creek aquifer observation wells used for transient simulations ....................................................... 29

7. Mean drawdown in the main body of the Split Rock Creek aquifer with additional pumping of 4 cubic feet per second

8. Comparison of simulated water budget for the main body of the Split Rock Creek aquifer of hypothetical average conditions to hypothetical average conditions with additional pumping of 4 cubic feet per second

9. Mean drawdown in the main body of the Split Rock Creek aquifer with additional pumping during June through August quarter of 10 cubic feet per second.

\section{CONVERSION FACTORS AND VERTICAL DATUM}

\begin{tabular}{rcl}
\hline Multiply & By & To obtain \\
\hline acre & 4,047 & square meter \\
acre & 0.4047 & hectare \\
acre-foot per year $($ acre- $\mathrm{ft} / \mathrm{yr})$ & 1,233 & cubic meter per year \\
cubic foot per second $(\mathrm{ft} / \mathrm{s})$ & 0.02832 & cubic meter per second \\
foot $(\mathrm{ft})$ & 0.3048 & meter \\
foot per day $(\mathrm{ft} / \mathrm{d})$ & 0.3048 & meter per day \\
foot per day per foot $[(\mathrm{ft} / \mathrm{d}) / \mathrm{ft}]$ & 1 & meter per day per meter \\
foot squared per day $\left(\mathrm{ft}{ }^{2} / \mathrm{d}\right)$ & 0.09290 & meter squared per day \\
mile $(\mathrm{mi})$ & 1.609 & kilometer \\
inch $(\mathrm{in})$. & 25.4 & millimeter \\
inch per year $(\mathrm{in} / \mathrm{yr})$ & 25.4 & millimeter per year \\
square mile $\left(\mathrm{mi}^{2}\right)$ & 2.590 & square kilometer \\
\hline
\end{tabular}

Sea level: In this report, "sea level" refers to the National Geodetic Vertical Datum of 1929 (NGVD of 1929) - a geodetic datum derived from a general adjustment of the first-order level nets of both the United States and Canada, formerly called Sea Level Datum of 1929. 


\section{WELL-NUMBERING SYSTEM}

Observation wells and test holes are numbered according to the Federal land survey system. This system uses township, range, and section number. Number 101N48W2CCCC indicates a well in T. 101 N., R. 48 W., section 2. The last four-letters show location within the section as shown below. When a nest of wells is drilled, sequential numbers identify each well in the nest and appear after the four-letter code.

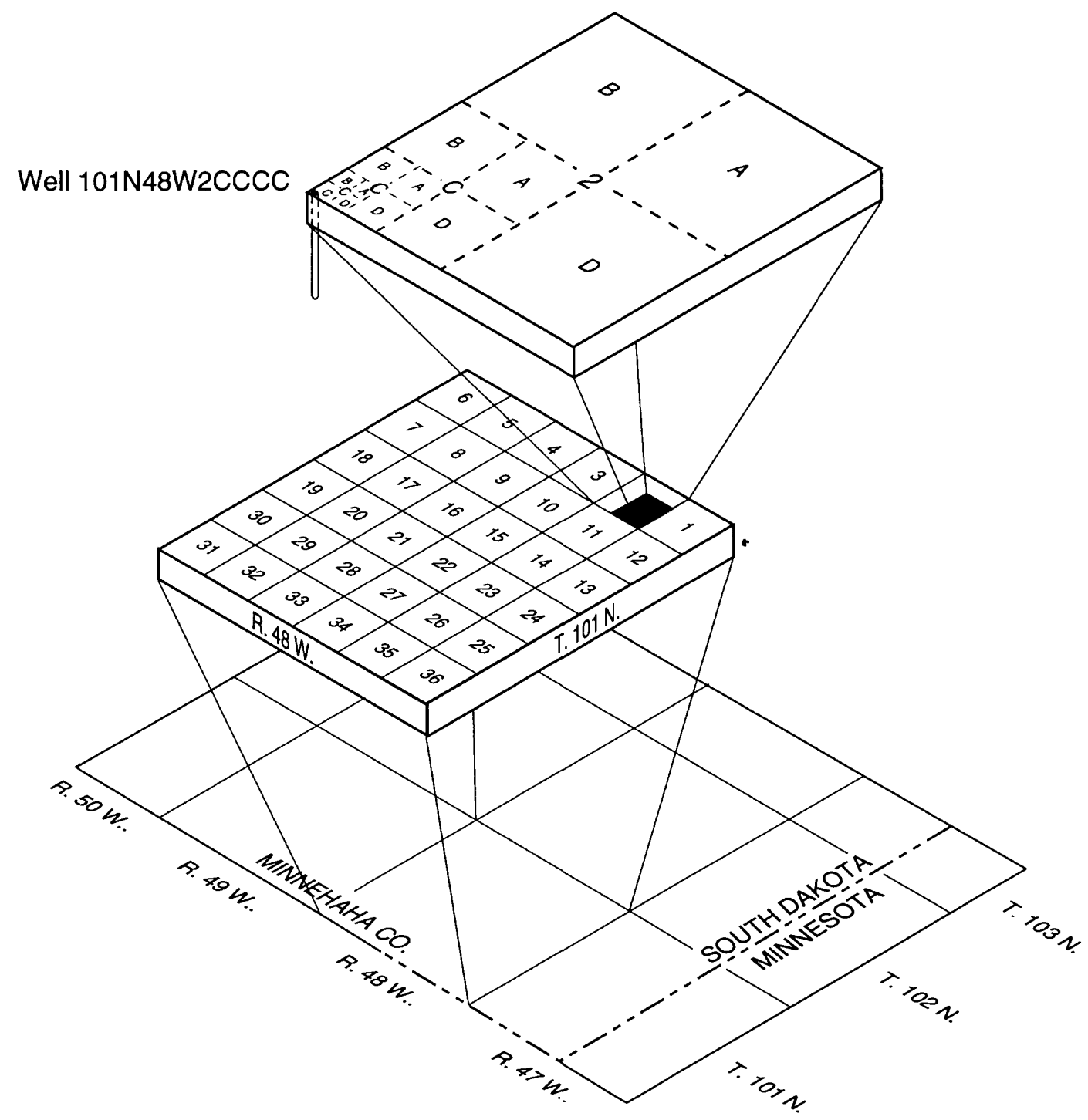




\title{
Hydrogeology of the Split Rock Creek Aquifer with Emphasis on Calibration of a Numerical Flow Model, Southeast Minnehaha County, South Dakota
}

\author{
By Larry D. Putnam
}

\section{ABSTRACT}

The Split Rock Creek aquifer in southeast Minnehaha County, South Dakota, consists of weathered quartzite, which was transported and deposited in a topographic low in the Sioux Quartzite. Recharge to the Split Rock Creek aquifer occurs from infiltration of precipitation and subsequent movement through the joints and fractures in the Sioux Quartzite. Discharge from the Split Rock Creek aquifer occurs vertically to overlying alluvium where the intervening layers are fractured siltstone and occurs horizontally to the Sioux Quartzite or permeable deposits overlying the Sioux Quartzite.

The Split Rock Creek aquifer was analyzed using a three-dimensional ground-water flow model. The ground-water system was conceptualized as three aquifer layers with a confining unit separating layers 1 and 2 . The upper layer represents the alluvial aquifers; the second and third layers represent the Split Rock Creek aquifer and the Sioux Quartzite aquifer. The finite-difference model grid blocks were 660 feet on a side, with 112 rows and 160 columns.

Hydraulic conductivity for the alluvial aquifers ranged from 200 to 300 feet per day. Transmissivity assigned to the Split Rock Creek aquifer ranged from 200 to 12,700 feet squared per day, with a mean of 2,100 feet squared per day. Mean transmissivity assigned to the Sioux Quartzite aquifer was 160 feet squared per day in layer 2 and 60 feet squared per day in layer 3. Storage coefficient assigned to the Split Rock
Creek aquifer was 0.00026. Mean vertical conductance assigned to the fractured siltstone separating the Split Rock Creek aquifer from the overlying alluvial aquifers was 0.002 foot per day per foot. Estimated average 1985-89 recharge was 5.0 inches per year to alluvial aquifers and averaged 3.0 inches per year to the Sioux Quartzite aquifer in and around outcrop areas.

The model was calibrated using steady-state simulation, transient quarterly simulation for 1990-92, and transient monthly simulation for 1993. The water budget for the main body of the Split Rock Creek aquifer for steady-state simulation showed inflow of 1.8 cubic feet per second from the Sioux Quartzite aquifer and 0.3 cubic foot per second from constant-head boundaries. Vertical outflow was 0.6 cubic feet per second to the Big Sioux aquifer and 0.6 cubic feet per second to the Brandon aquifer, and horizontal outflow of 0.9 cubic feet per second to the Sioux Quartzite and Big Sioux aquifers. The model was most sensitive to changes in recharge to the Sioux Quartzite aquifer, vertical conductance between the Split Rock Creek aquifer and the alluvial aquifers, and transmissivity of the Split Rock Creek aquifer. The average difference between simulated and observed hydraulic heads was -0.4 foot for the steady-state simulation, +2.7 feet for the transient quarterly simulations, and +0.4 foot for the transient monthly simulations. Hypothetical simulations of an average year divided into quarterly stress periods, with seasonal variation in stresses repeated for 3 years, were compared to the same simulations with additional pumping to evaluate 
the water-supply potential of the Split Rock Creek aquifer. Drawdown after 3 years was greater than 20 feet in an area of approximately 20 square miles with additional pumping of 4.0 cubic feet per second. A new equilibrium was reached by induced recharge of 0.8 cubic foot per second from the Sioux Quartzite aquifer and 2.6 cubic feet per second from alluvial aquifers. A similar hypothetical simulation of average conditions with seasonal pumping of 10 cubic feet per second during the summer quarter indicated that partial recovery would occur. Drawdown greater than 20 feet at the end of the summer quarter of the third year included an area of approximately 34 square miles.

\section{INTRODUCTION}

The City of Sioux Falls is seeking an additional water source to meet future demand. Lindgren and Niehus (1992) describe the Split Rock Creek aquifer in southeast Minnehaha County as a potential supply of water. The City of Sioux Falls and East Dakota Water Development District entered into a cooperative agreement with the U.S. Geological Survey to use numerical ground-water flow modeling to help evaluate the development potential of the Split Rock Creek aquifer. Results also will provide improved understanding of ground-water systems in similar geologic settings.

The general approach to study the Split Rock Creek aquifer was to collate geological and hydrological data to conceptualize the ground-water flow system in the study area (fig. 1). Since the report of Lindgren and Niehus (1992), additional data were collected by the South Dakota Department of Environment and Natural Resources, Division of Geological Survey, hereinafter referred to as the South Dakota Geological Survey. These additional data were utilized in refining the conceptual model of the ground-water flow system and constructing a numerical model.

Specific objectives of the study were to:

(1) describe the hydrologic characteristics of the Split Rock Creek aquifer in southeast Minnehaha County, (2) analyze the hydrologic system using the numerical ground-water flow model, and (3) preliminarily evaluate the water-supply potential of the Split Rock Creek aquifer south and east of Brandon using the calibrated ground-water flow model.

\section{Purpose and Scope}

The purpose of this report is to document the development, calibration, and use of the numerical model. Data from previous studies, additional test-hole logs, and aquifer tests conducted by the South Dakota Geological Survey were used to determine the extent, thickness, and hydraulic properties of the Split Rock Creek aquifer and adjacent formations. Fifty test holes were completed (1989-93) using the mud rotary drilling method with a Failing 1500 drilling rig (Pence, 1996). Steady-state simulation of assumed average hydrologic conditions (1985-89) prior to significant pumping from the aquifer and transient simulation of 1990-93, which includes pumping stresses and varying climatic conditions, were used to calibrate the model. A predictive evaluation of the effects of additional pumping stresses on the potentiometric surface in the aquifer was made using the calibrated model.

\section{Previous Investigations}

Bretz (1981) summarizes the history of geological investigations in the area of the Split Rock Creek Formation in a section of the Iowa Geological Survey Guidebook Series describing the Cretaceous stratigraphy and sedimentation in northwest Iowa, northeast Nebraska, and southeast South Dakota. Ludvigson and others (1981) formally proposed the name Split Rock Creek Formation and describe the lithostratigraphy and sedimentary petrology of the late Cretaceous deposits.

Earlier reports by Rothrock (1958) and R.L. Stach (South Dakota Geological Survey, written commun., 1970) recognized the formation as a single depositional unit and describe the general geology and mineralogy. The sedimentology, stratigraphy, and depositional history are described by Suzanne Kairo (Purdue University, written commun., 1987) utilizing additional information. A study of the geology of Minnehaha County (Tomhave, 1994) and the water resources of Minnehaha County (Lindgren and Niehus, 1992) include additional data and interpretations of the Split Rock Creek Formation. Chandler (1994) investigated the thickness and potential ground-water resources of Cretaceous and Quaternary sediments in Rock County, Minnesota. Pence (1996) describes the additional test drilling and interpretations of the hydrogeology of the Split Rock Creek Formation. 


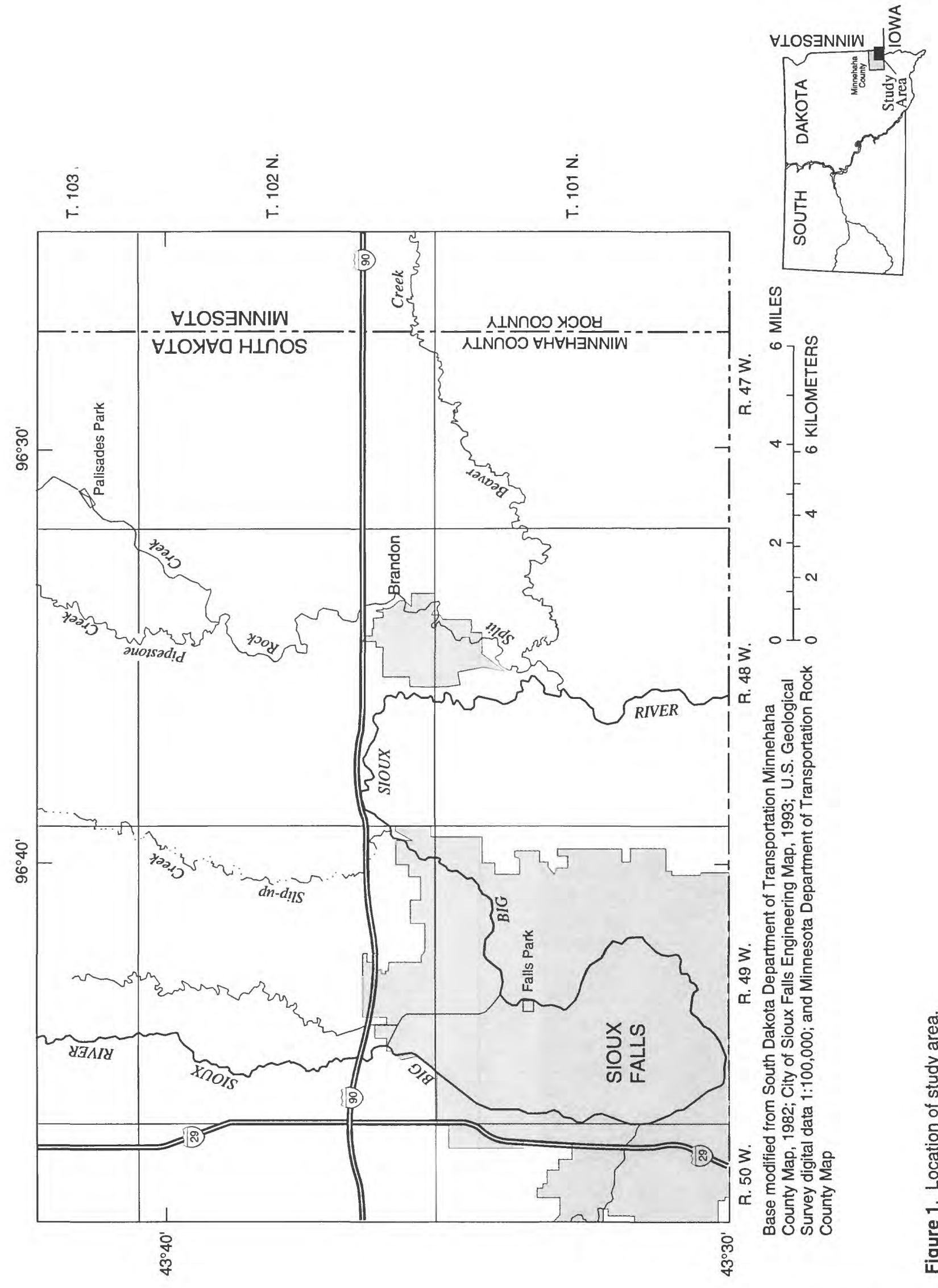




\section{Acknowledgments}

The author acknowledges the numerous unpublished data summaries and interpretations of the hydrogeology of the Split Rock Creek aquifer provided by Stan Pence, Tim Cowman, and Assad Barari of the South Dakota Geological Survey. The City of Sioux Falls and City of Brandon staffs also supplied pumping records and additional well logs.

\section{HYDROGEOLOGY}

\section{Geologic Setting}

The Split Rock Creek Formation is made up of sedimentary deposits during Late Cretaceous time in a local topographic depression on the Precambrian rocks of the Sioux Quartzite along the eastern margin of the Cretaceous Western Interior seaway (Ludvigson and others, 1981). The formation represents the transgressive sequence of sediment deposited in embayments in the Sioux Quartzite surface as Cretaceous seas encroached upon South Dakota, Minnesota, and Iowa (Suzanne Kairo, Purdue University, written commun., 1987).

Weathering and deterioration before the Cretaceous Period of the exposed irregular surface of the Sioux Quartzite over extended time resulted in the deposition of a rounded quartzite sand in the paleotopographic lows with some interbedding of organic rich clays and coals comprising the Split Rock Creek Formation. The lithology fines upward through a sequence of clayey siltstones and silty claystones followed by organic-rich opaline sediments, and chert (Suzanne Kairo, Purdue University, written commun., 1987).

The embayment containing the thicker sand deposits of the Split Rock Creek Formation is within the 20 - by 14 -mi study area in the southeast corner of Minnehaha County, South Dakota, and west Rock County, Minnesota. The informally named Brandon embayment (Suzanne Kairo, Purdue University, written commun., 1987) is a depression parallel to the strike of the Sioux Quartzite in southeast Minnehaha County. A map of the Sioux Quartzite surface in southeast Minnehaha County (fig. 2) shows the deepest part of the depression exceeding $500 \mathrm{ft}$ in relation to the quartzite outcrop areas around the perimeter of the embayment. The embayment includes the entire trough along the north edge of T. 101 N., R. 48. W. and T. 101 N., R. 47 W. The lower part of the Split Rock Creek Formation in the Brandon Embayment is described by Tomhave (1994) as consisting of as much as $240 \mathrm{ft}$ of fine- to medium-grained pink sand.
The upper Precambrian Sioux Quartzite underlying the Split Rock Creek Formation is described by R.E. Weber (University of Minnesota, written commun., 1981) as a thick, gently dipping sequence of sedimentary orthoquartzite with minor interbedded siliceous conglomerate and mudstones. No evidence of faulting has been observed in outcrops in eastern South Dakota. Vertical and horizontal jointing is well developed with spacing that varies from a few inches to several feet in exposures and where traversed by rivers erodes to nearly vertical cliffs (Tomhave, 1994).

The bedrock formations are overlain by glacial till and outwash deposited by a complex sequence of glacial advances dating from Pre-Illinoian to Late Wisconsin. The significant glacial deposits in the appraisal of the Split Rock Creek aquifer are alluvial deposits associated with the current drainage and terrace remnants of earlier alluvial deposits directly overlying the Split Rock Creek Formation or the Sioux Quartzite. Alluvial sediments and terrace remnants along the Big Sioux River and Split Rock Creek overlie the Split Rock Creek Formation. Similar deposits along Pipestone Creek and the Big Sioux River in the south-central part of the study area overlie the Sioux Quartzite. Similar deposits along Beaver Creek are separated from the underlying bedrock formations by relatively impermeable sediments.

\section{Conceptual Model of the Ground-Water System}

The extent of the Split Rock Creek aquifer in the study area (fig. 3) conforms to the shape of the Brandon embayment. Slight modification of the areal extent from the water-resources investigation of Minnehaha County (Lindgren and Niehus, 1992) is based on additional test-hole drilling and interpretation (Pence, 1996). Hydrogeologic section A-A' (fig. 4) shows the vertical relationship of the Split Rock Creek aquifer to the Sioux Quartzite aquifer, and the overlying Pipestone Creek, Brandon, and Big Sioux aquifers (fig. 5). Hydraulic connections between bedrock aquifers and overlying alluvial aquifers (fig. 4) are possible where relatively impermeable glacial tills are absent.

The Split Rock Creek aquifer is under confined conditions in the study area except for a small area near 102N49W14CCCC. The hydraulic head in the Split Rock Creek aquifer in an area south and east of Brandon where the aquifer is the thickest, is generally greater than $100 \mathrm{ft}$ above the top of the Split Rock Creek aquifer. 


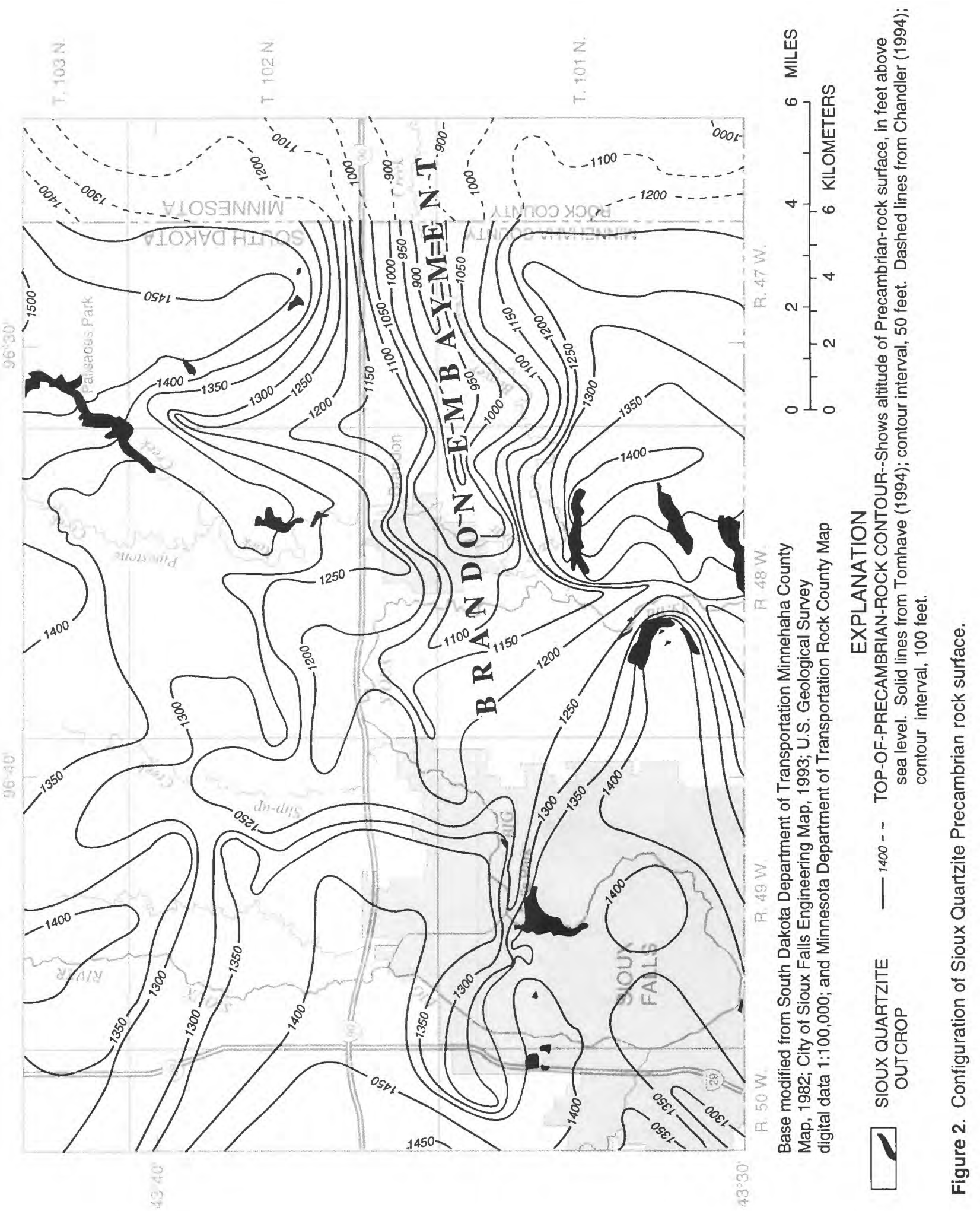




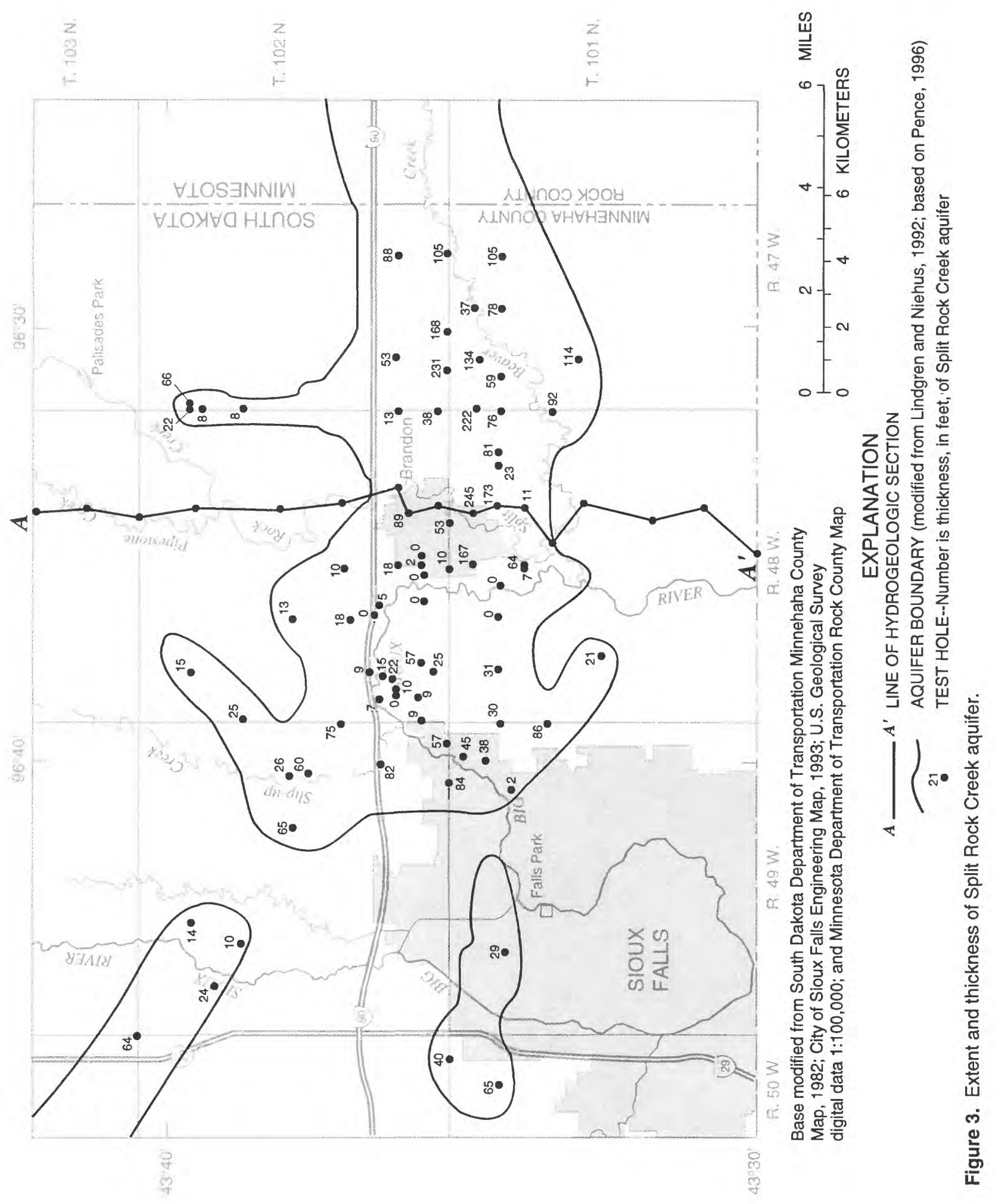



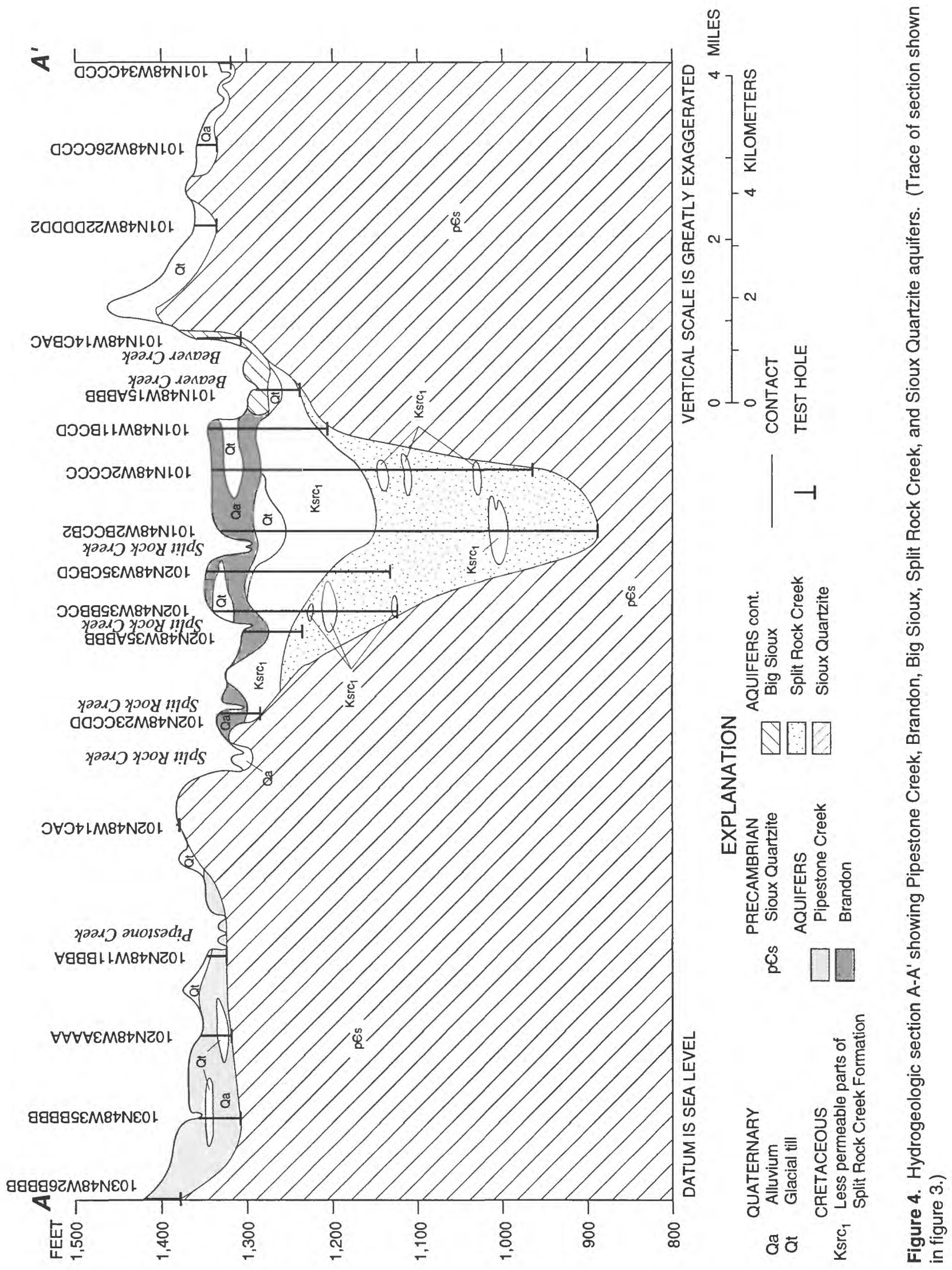


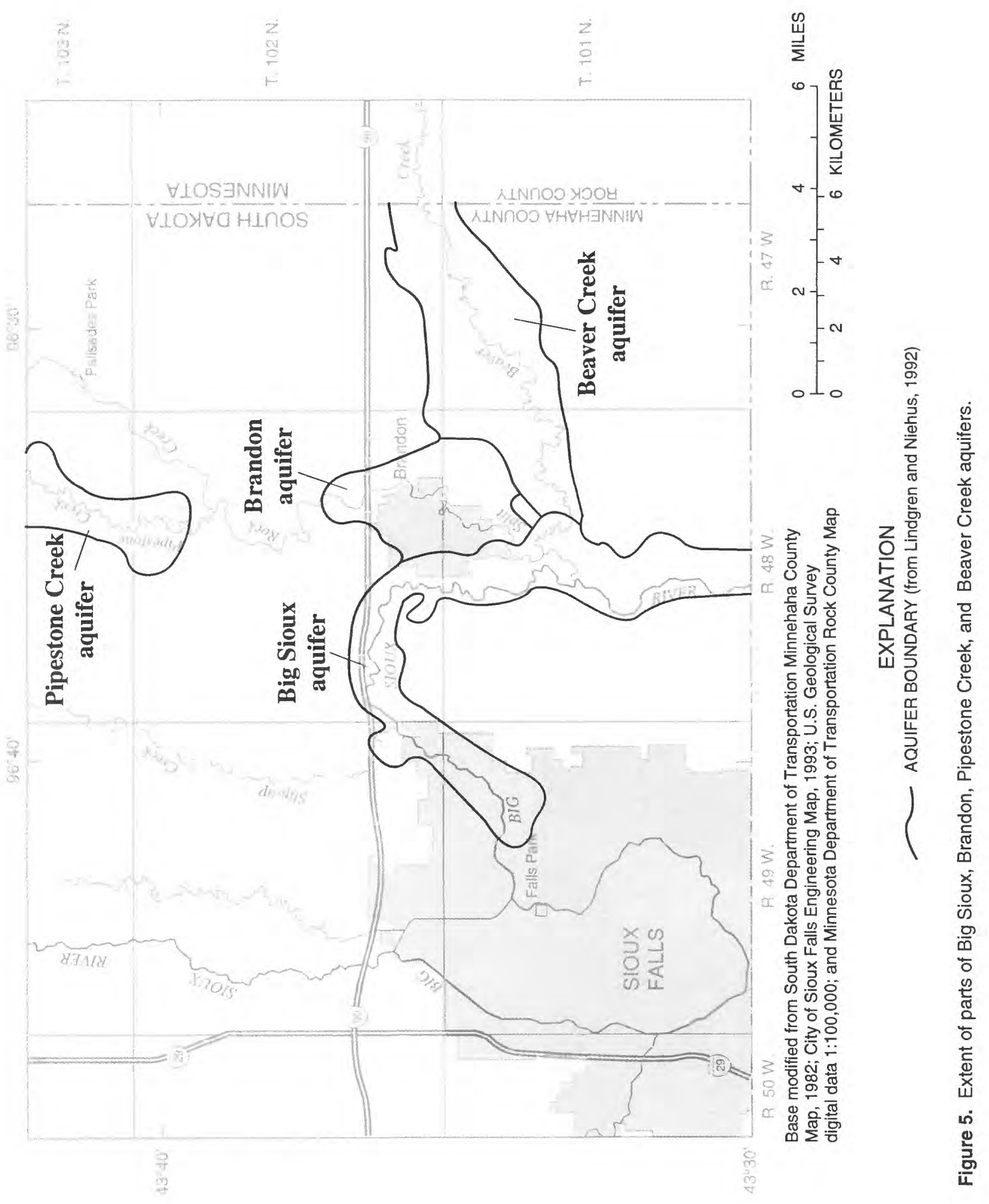


The general ground-water flow direction in the Split Rock Creek aquifer (fig. 6) is from north to south converging beneath the Big Sioux River flood plain in the south-central part of the study area. Observed hydraulic-head measurements were based on landsurface altitudes interpreted from topographic maps with 10-ft contour intervals for many of the observation wells while some were based on surveyed altitudes. Infiltration of precipitation moves through the fractures and joints of the Sioux Quartzite to the Split Rock Creek aquifer. Inflow to the Split Rock Creek aquifer occurs from the Sioux Quartzite on the north, west, and near topographic highs where the Sioux Quartzite outcrops or is overlain by shallow permeable sediments. To characterize flow to the Split Rock Creek aquifer from the Sioux Quartzite aquifer, the potentiometric surface in the Sioux Quartzite aquifer was estimated.

The generalized potentiometric surface in the Sioux Quartzite aquifer surrounding the Split Rock Creek aquifer (fig. 6) was inferred from water-level measurements in private wells in the Sioux Quartzite aquifer (Stan Pence, South Dakota Geological Survey, Vermillion, S. Dak, written commun., 1993); waterlevel measurements in alluvial aquifers where test holes indicate hydraulic connections to the Sioux Quartzite aquifer; previous studies in adjacent areas (Anderson and others, 1986; Burkart, 1984); waterlevel measurements in the Split Rock Creek aquifer; and land-surface topography. Regional ground-water flow in the Sioux Quartzite aquifer is to the south and southwest (fig. 6) with alterations by hydraulic connections to alluvial aquifers overlying the valleys in the quartzite (Lindgren and Niehus, 1992).

The potentiometric surface at the extreme northwest corner was determined from water levels measured in wells cased in the Split Rock Creek aquifer on each side of the study area boundary. Hydraulic head was decreased linearly moving east towards the measured water levels in the hydraulically connected Pipestone Creek aquifer. From the Pipestone Creek aquifer to 2 mi east of Split Rock Creek, the flow direction was assumed to be toward the Pipestone Creek aquifer or Split Rock Creek.

The potentiometric surface along the northeast edge of the study area was modified from Anderson and others (1976) to reflect a low in the surface of the Sioux Quartzite (fig. 2; Chandler, 1994). The low contains valley-fill sediments made up of interbedded shales and eroded quartzite (R.J. Lindgren, U.S.
Geological Survey, written commun., 1994). The flow direction was interpreted as predominantly to the south because the transmissivity of the eroded quartzite in the low area was assumed to be higher than the surrounding Sioux Quartzite aquifer. The potentiometric surface from the Split Rock Creek aquifer to the south corner of the study area was determined from measured hydraulic heads in the Split Rock Creek aquifer and the regional potentiometric surface of the Sioux Quartzite aquifer (Anderson and others, 1976).

Estimates of the potentiometric surface in the Sioux Quartzite aquifer at the southeast edge of the study area were based on the potentiometric surface of the overlying Dakota aquifer in northwest Iowa (Burkart, 1984), which shows an altitude at the South Dakota-Iowa border of approximately $1,275 \mathrm{ft}$. Testhole logs indicated possible hydraulic connection between the Dakota aquifer and the Sioux Quartzite aquifer. The assumed flow direction along the southcentral area was from the outcrop areas of the Sioux Quartzite aquifer towards the hydraulically connected Big Sioux aquifer. The potentiometric surface along the east edge of the study area was interpolated between measured hydraulic heads in the Split Rock Creek aquifer and the Sioux Quartzite aquifer. Water levels measured in the alluvium overlying the Sioux Quartzite near the edge of the study area also were used as a guide in interpreting the potentiometric surface.

The upper part of the Split Rock Creek Formation overlying the Split Rock Creek aquifer and the adjacent Sioux Quartzite aquifer is made up of interbedded shales (relatively impermeable) and fractured siltstones and claystones. Sediments overlying the Split Rock Creek aquifer, as indicated by test-hole logs, consist mostly of fractured siltstone in the flood plain of Split Rock Creek east of Brandon and in the flood plain of the Big Sioux River in the southeast corner of T. 102 N., R. 49 W. and the southwest corner of T. 102 N., R. 48 W. Loss of drilling fluid during drilling of test holes for this study was common in the siltstone and claystone, indicating the potential for leakage to and from overlying unconfined alluvial aquifers. Water flowed from test hole 101N48W15ABBB, when drilled in 1979, which penetrated siltstone overlying the quartzite at the south perimeter of the Split Rock Creek aquifer in the flood plain of the Big Sioux River. Vertical leakage to and from the overlying alluvial aquifers is very small in areas separated by shale and glacial till. 


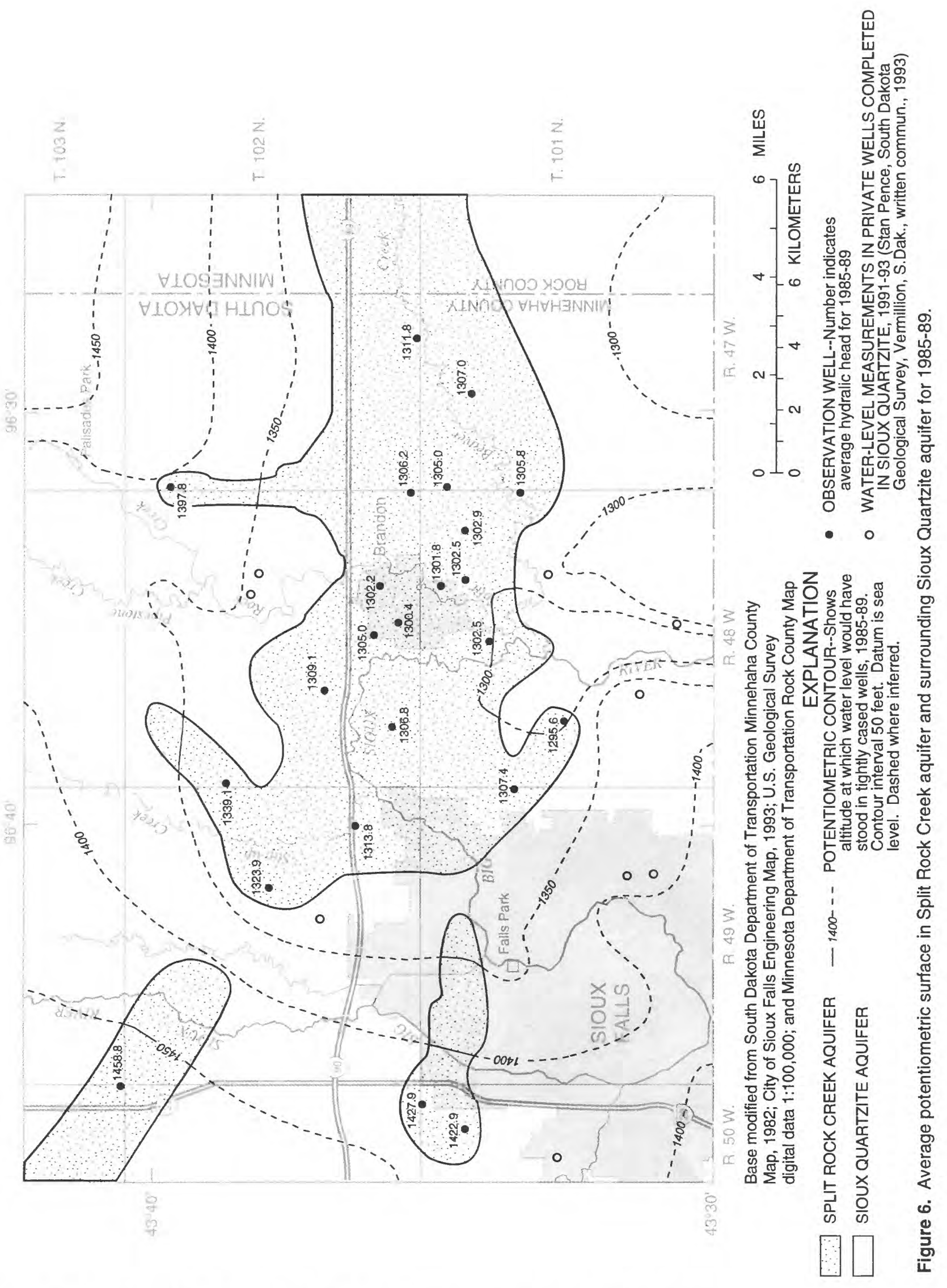


Water-level fluctuations at well 102N48W 30ADDD in the Big Sioux aquifer (fig. 7) reflects above-average precipitation during 1985-86, belowaverage precipitation during 1987-90, and above-average precipitation during 1991-93. Hydraulic head in the Split Rock Creek aquifer at well $102 \mathrm{~N} 48 \mathrm{~W} 32 \mathrm{BCDC}$ shows a similar response to precipitation also indicating a hydraulic connection to the overlying alluvial aquifers. The decline in hydraulic head in 1990 is due to municipal pumping at two new wells east of Sioux Falls and an existing well south of Brandon beginning in September 1990. The recovery in water levels into 1993 coincides with above-average precipitation.

\section{Hydraulic Properties}

Transmissivity determined from seven fully penetrating aquifer tests in the Split Rock Creek aquifer (Pence, 1996) range from $600 \mathrm{ft}^{2} / \mathrm{d}$ (10 ft of aquifer thickness) to $10,000 \mathrm{ft}^{2} / \mathrm{d}$ ( $240 \mathrm{ft}$ of aquifer thickness). Four of the tests were located along the northeast edge of Sioux Falls, one about 4 mi north of Sioux Falls, and two near Brandon. Hydraulic conductivity determined from the seven tests ranged from 23 to $61 \mathrm{ft} / \mathrm{d}$ with an average of $48 \mathrm{ft} / \mathrm{d}$. Storage coefficients ranged from $6.8 \times 10^{-5}$ to $5.3 \times 10^{-3}$.

Hydraulic conductivities for the fractured siltstone (Pence, 1996) determined from slug tests at two wells completed in the siltstone northeast of Sioux Falls were 0.3 and $1.1 \mathrm{ft} / \mathrm{d}$. Vertical hydraulic conductivity of $0.003 \mathrm{ft} / \mathrm{d}$ was estimated from data from an aquifer test (Stan Pence, South Dakota Geological Survey, written commun., 1993) conducted at the City of Brandon municipal well using the method described by Hantush and Jacob (1955) for leaky confined aquifers. The value provides only an estimate because the area of siltstone without intervening shale layers exists only in the flood plain of Split Rock Creek, which overlies less than one-half of the aquifer-test drawdown cone.

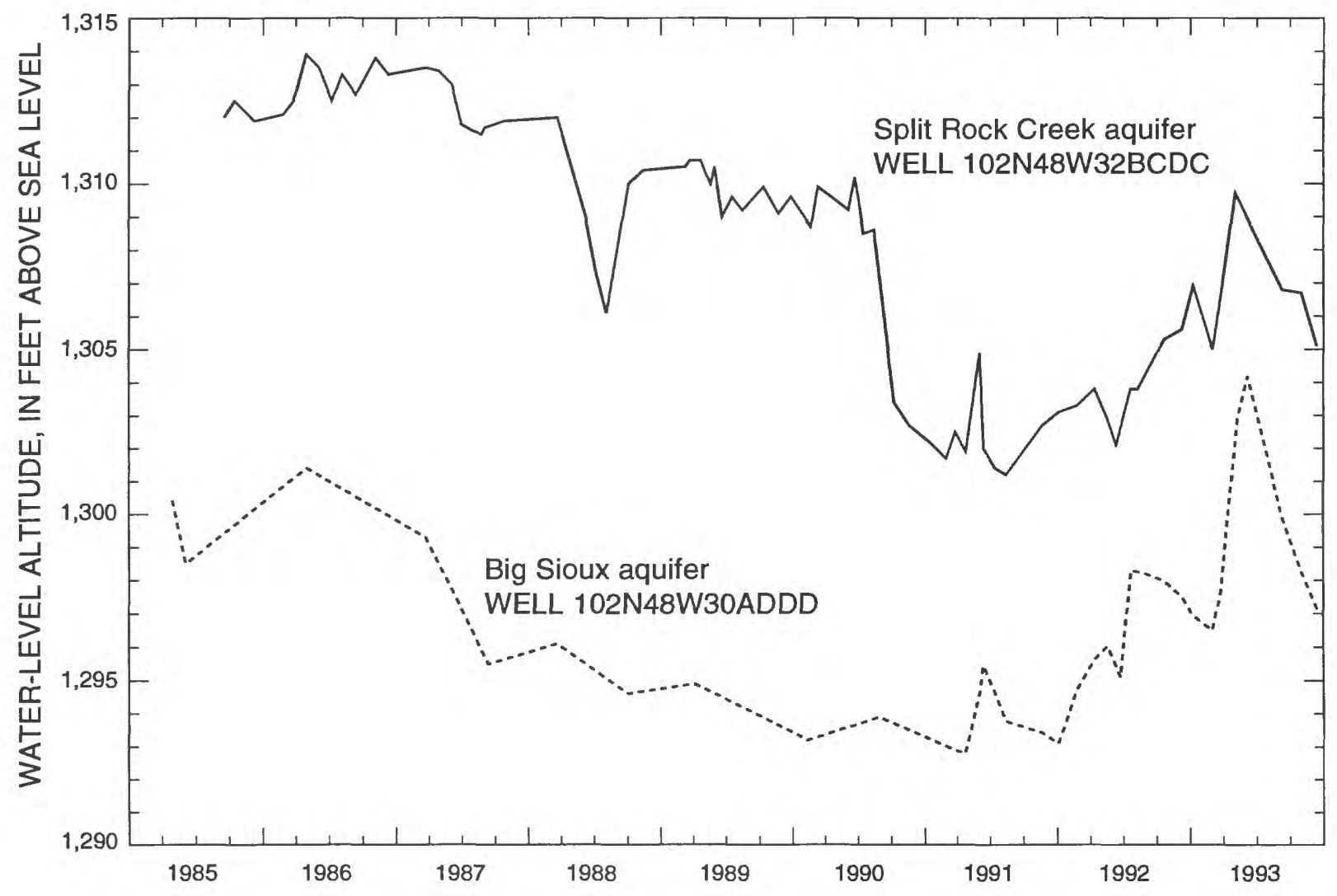

Figure 7. Comparison of hydraulic head in Split Rock Creek aquifer with that in Big Sioux aquifer. 
The ability of the Sioux Quartzite aquifer to transmit water is primarily due to joints and fractures. This hydraulic conductivity decreases with depth (Anderson, 1986). Transmissivity determined from seven aquifer tests in the Sioux Quartzite aquifer in adjacent Rock and Pipestone Counties, Minnesota (Kanivetsky and Walton, 1986) ranged from 20 to $940 \mathrm{ft}^{2} / \mathrm{d}$.

The movement of water between streams and alluvial aquifers is a function of the hydraulic properties of the streambed material. Laboratory analysis of streambed material collected from the Big Sioux River north of the study area (Jorgensen and Ackroyd, 1973) determined hydraulic conductivities of 0.5 to $1 \mathrm{ft} / \mathrm{d}$. A hydraulic conductivity determined from in-situ experiments and analysis of a clayey silt in a nearby diversion canal with lower stream velocities was $0.01 \mathrm{ft} / \mathrm{d}$ (R.C. Thompson, U.S. Geological Survey, written commun., 1994).

\section{Recharge and Discharge}

Recharge to the alluvial aquifers is from infiltration of precipitation. The range of average recharge determined from earlier model studies of similar alluvial aquifer systems adjacent to the study area ranged from $4.5 \mathrm{in} / \mathrm{yr}$ (R.C. Thompson, U.S. Geological Survey, written commun., 1994) to $6.0 \mathrm{in} / \mathrm{yr}$ (Ohland, 1990). Average precipitation at Sioux Falls from 1961 to 1990 was 23.86 in. (National Oceanic and Atmospheric Administration, 1993).

Recharge to the Sioux Quartzite aquifer is from infiltration of precipitation through joints and fractures at outcrop areas and areas overlain by permeable sediments as interpreted from well logs. Anderson (1986) describes the outcrops as areas of great secondary hydraulic conductivity that decreases with depth. An assumption was made that the infiltration rate to the Sioux Quartzite aquifer would be somewhat less than that for the alluvial aquifers due to the lower hydraulic conductivity of the fractured rock. Streams that traverse quartzite outcrops generally recharge the Sioux Quartzite aquifer, however, discharge probably occurs at Palisades Park and Falls Park where vertical walled canyons and waterfalls have formed in the quartzite. Palisades Park is located on the outcrop (fig. 2) along Split Rock Creek in the northeast part of the study area. Falls Park is located on the outcrop (fig. 2) along the Big Sioux River in Sioux Falls.
Seasonal recharge (table 1) was estimated by multiplying precipitation data (U.S. Department of Commerce, 1985-93) with an empirical multiplication factor based on seasonal changes in soil conditions and moisture utilized for plant growth. For the months of December, January, and February, the recharge multiplication factor was 0.05 due to frozen soil conditions. For the months of March, April, and May, the recharge multiplication factor was 0.30 due to the contribution of snowmelt and minimum moisture withdrawal by plant growth. For the months of June, July, and August, the recharge multiplication factor was 0.18 due to the utilization of soil moisture by plant roots before reaching the aquifer. For the months of September, October, and November, the recharge multiplication factor was 0.23 due to declining utilization of soil moisture by plant roots. The sum of the quarterly recharge fluxes for an average year was $5.3 \mathrm{in} / \mathrm{yr}$. During sustained periods of above-average (1961-90) rainfall, a larger part of rainfall was assumed to contribute to runoff instead of infiltration. An empirical adjustment was made to account for decreased infiltration with a saturated soil profile or high rainfall intensity. When precipitation was greater than 1.0 in. above the average for the period, the amount of precipitation above average contributing to infiltration was reduced by 1 percent for each $0.1 \mathrm{in}$. that the precipitation was above average. Recharge to the Sioux Quartzite aquifer was assumed to be 80 percent of that estimated for the alluvial aquifers.

The potential evapotranspiration rate from the alluvial aquifers and Sioux Quartzite aquifer where exposed was estimated to be 70 percent of the class A pan evaporation (Farnsworth and Thompson, 1982). The average pan evaporation rate determined from climatological data for South Dakota at Sioux Falls (U.S. Department of Commerce, 1985-93) was $51.4 \mathrm{in} / \mathrm{yr}$, which equates to $36 \mathrm{in}$. of potential evapotranspiration per year.

Ground water in the study area is used for domestic, municipal, and industrial water supplies. The small amount used for industrial and domestic supplies was assumed to have negligible effect on the aquifers. Water use by the City of Brandon during 1985-89 averaged $0.04 \mathrm{ft}^{3} / \mathrm{s}$ from the Split Rock Creek aquifer and $0.46 \mathrm{ft}^{3} / \mathrm{s}$ from the Big Sioux and Brandon aquifers.

Pumping withdrawal from the Split Rock Creek aquifer between 0.4 to $0.7 \mathrm{ft}^{3} / \mathrm{s}$ per well began in 1990 at two Sioux Falls municipal wells on the northeast 
edge of Sioux Falls and one Brandon municipal well south of Brandon. Average pumping rates are shown in table 2. The lack of pumping at the two well sites near Sioux Falls in June and July 1993 was due to flooding conditions along the Big Sioux River.

\section{NUMERICAL MODEL}

\section{Model Design}

MODFLOW, the U.S. Geological Survey numerical three-dimensional finite-difference groundwater flow model (McDonald and Harbaugh, 1988), with modifications to read and write geographic infor- mation system files (Orzol and McGrath, 1992), was used to study the hydrology of the Split Rock Creek aquifer. The model program uses a digital computer to obtain solutions to a set of finite-difference equations that approximate the partial differential equations describing ground-water flow. The strongly implicit numerical method was used to solve the series of discrete algebraic equations. A detailed description of the program appears in McDonald and Harbaugh (1988) and is available from the U.S. Geological Survey.

The general approach to calibration of the model representing the Split Rock Creek aquifer was to simulate a period approximating average conditions prior to significant pumping stresses with a steady-state simulation followed by transient simulations of changing hydrologic stresses. The period from $1985-89$ was

Table 1. Seasonal recharge rate

\begin{tabular}{|c|c|c|c|c|c|}
\hline Time period & $\begin{array}{l}\text { Recharge } \\
\text { multiplication } \\
\text { factor }^{1}\end{array}$ & $\begin{array}{l}\text { Precipitation } \\
\text { (inches) }\end{array}$ & $\begin{array}{l}\text { Average } \\
\text { precipitation } \\
\text { (1961-90) } \\
\text { (inches) }\end{array}$ & $\begin{array}{l}\text { Adjusted } \\
\text { precipitation } \\
\text { (inches) }\end{array}$ & $\begin{array}{c}\text { Maximum } \\
\text { recharge rate } \\
\text { to aquifers }{ }^{2} \\
\text { (inches per year) }\end{array}$ \\
\hline December 1989-February 1990 & 0.05 & 0.64 & 1.52 & 0.64 & 0.1 \\
\hline March 1990-May 1990 & .30 & 7.50 & 7.16 & 7.50 & 9.0 \\
\hline June 1990-August 1990 & .18 & 7.80 & 9.10 & 7.80 & 5.6 \\
\hline September $1990-$ November 1990 & .23 & 2.90 & 6.24 & 2.90 & 2.7 \\
\hline December 1990-February 1991 & .05 & 1.17 & 1.52 & 1.17 & .2 \\
\hline March 1991-May 1991 & .30 & 9.27 & 7.16 & 9.06 & 1.9 \\
\hline June 1991-August 1991 & .18 & 10.03 & 9.10 & 10.03 & 7.2 \\
\hline September 1991-November 1991 & .23 & 7.38 & 6.24 & 7.25 & 6.7 \\
\hline December 1991-February 1992 & .05 & 2.71 & 1.52 & 2.59 & .5 \\
\hline March 1992-May 1992 & .30 & 6.17 & 7.16 & 6.17 & 7.4 \\
\hline June 1992-August 1992 & .18 & 16.14 & 9.10 & 11.19 & 8.5 \\
\hline September 1992-November 1993 & .23 & 6.82 & 6.24 & 6.82 & 6.3 \\
\hline December 1992 & .05 & .83 & .61 & .83 & .5 \\
\hline January 1993 & .05 & .70 & .47 & .70 & .4 \\
\hline February 1993 & .05 & .81 & .44 & .81 & .5 \\
\hline March 1993 & .30 & 2.04 & 1.73 & 2.04 & 7.3 \\
\hline April 1993 & .30 & 2.61 & 2.55 & 2.61 & 9.4 \\
\hline May 1993 & .30 & 8.26 & 2.88 & 5.36 & 19.3 \\
\hline June 1993 & .18 & 6.43 & 3.70 & 5.67 & 12.2 \\
\hline July 1993 & .18 & 7.86 & 2.60 & 5.04 & 10.9 \\
\hline August 1993 & .18 & 3.10 & 2.80 & 3.10 & 6.7 \\
\hline September 1993 & .23 & 1.88 & 3.00 & 1.88 & 5.2 \\
\hline October 1993 & .23 & .62 & 1.83 & .62 & 1.7 \\
\hline November 1993 & .23 & 1.50 & 1.41 & 1.50 & 4.1 \\
\hline
\end{tabular}

${ }^{1}$ Empirical factor to adjust infiltration for seasonal changes in soil conditions and moisture consumption by plant growth.

${ }^{2}$ Adjusted precipitation multiplied by recharge multiplication factor divided by the length of the time period in years. 
Table 2. Average municipal pumping rates

[Rates in cubic feet per second]

\begin{tabular}{|c|c|c|c|}
\hline Time period & $\begin{array}{c}\text { Brandon pumping, } \\
\text { Big Sioux aquifer and Bran- } \\
\text { don aquifer }{ }^{1}\end{array}$ & $\begin{array}{l}\text { Brandon pumping, } \\
\text { Split Rock Creek aquifer }\end{array}$ & $\begin{array}{l}\text { Sioux Falls pumping, } \\
\text { Split Rock Creek aquifer }\end{array}$ \\
\hline $1985-89$ average & 0.42 & 0.04 & \\
\hline December 1989-February 1990 & .03 & .38 & -- \\
\hline March 1990-May 1990 & .19 & .36 & -- \\
\hline June 1990-August 1990 & .27 & .59 & -- \\
\hline September 1990-November 1990 & -- & .30 & 1.15 \\
\hline December 1990-February 1991 & .02 & .34 & 1.26 \\
\hline March 1991-May 1991 & .03 & .48 & 1.14 \\
\hline June 1991-August 1991 & .17 & .74 & 1.05 \\
\hline September 1991-November 1991 & .48 & .48 & 1.25 \\
\hline December 1991-February 1992 & .24 & .19 & .96 \\
\hline March 1992-May 1992 & .13 & .22 & .97 \\
\hline June 1992-August 1992 & .32 & .26 & .95 \\
\hline September 1992-November 1993 & .24 & .26 & .75 \\
\hline December 1992 & .46 & -- & .60 \\
\hline January 1993 & .48 & -- & .77 \\
\hline February 1993 & .42 & - & .85 \\
\hline March 1993 & .09 & .40 & .73 \\
\hline April 1993 & .06 & .41 & .03 \\
\hline May 1993 & .03 & .51 & .98 \\
\hline June 1993 & .01 & .50 & .09 \\
\hline July 1993 & -- & .50 & - \\
\hline August 1993 & .15 & .59 & .58 \\
\hline September 1993 & -- & .57 & 1.19 \\
\hline October 1993 & .02 & .51 & 1.13 \\
\hline November 1993 & .04 & .40 & .80 \\
\hline
\end{tabular}

${ }^{1}$ Tabulated from pumping records supplied by the City of Brandon, S. Dak.

${ }^{2}$ Tabulated from pumping records supplied by the City of Sioux Falls, S. Dak.

selected to represent a period approximating average conditions because average precipitation for the period was 22.25 in. compared to 23.86 in. for 1961-90. Transient simulation of the period from 1990 through 1993 was selected because of changing stresses and the availability of water-level monitoring records.

Because recharge to and discharge from the Split Rock Creek aquifer occurs as flow to and from adjacent fractured rock units, the approach used to model the Split Rock Creek aquifer was to include also the Sioux Quartzite, fractured siltstones, and alluvial aquifers in a three-dimensional model. The purpose in modeling the adjacent units was to provide the most plausible boundary conditions for analyzing the Split Rock
Creek aquifer, not to evaluate the adjacent units. The stratigraphy described by part of hydrogeologic section $\mathrm{A}-\mathrm{A}^{\prime}$ and the corresponding representation in the model (fig. 8) shows the simplification of the groundwater flow system into three aquifer layers. Simulated ground-water flow was horizontal in the aquifer layers and vertical in the confining bed.

The model study area was divided into 10-acre grid blocks $660 \mathrm{ft}$ on a side with 112 rows and 160 columns (figs. $9-11$ ). The 14 - by 20 -mi model study area was centered on the thicker deposits of sand in the Split Rock Creek aquifer and the areas hydraulically connected to overlying alluvial aquifers. 


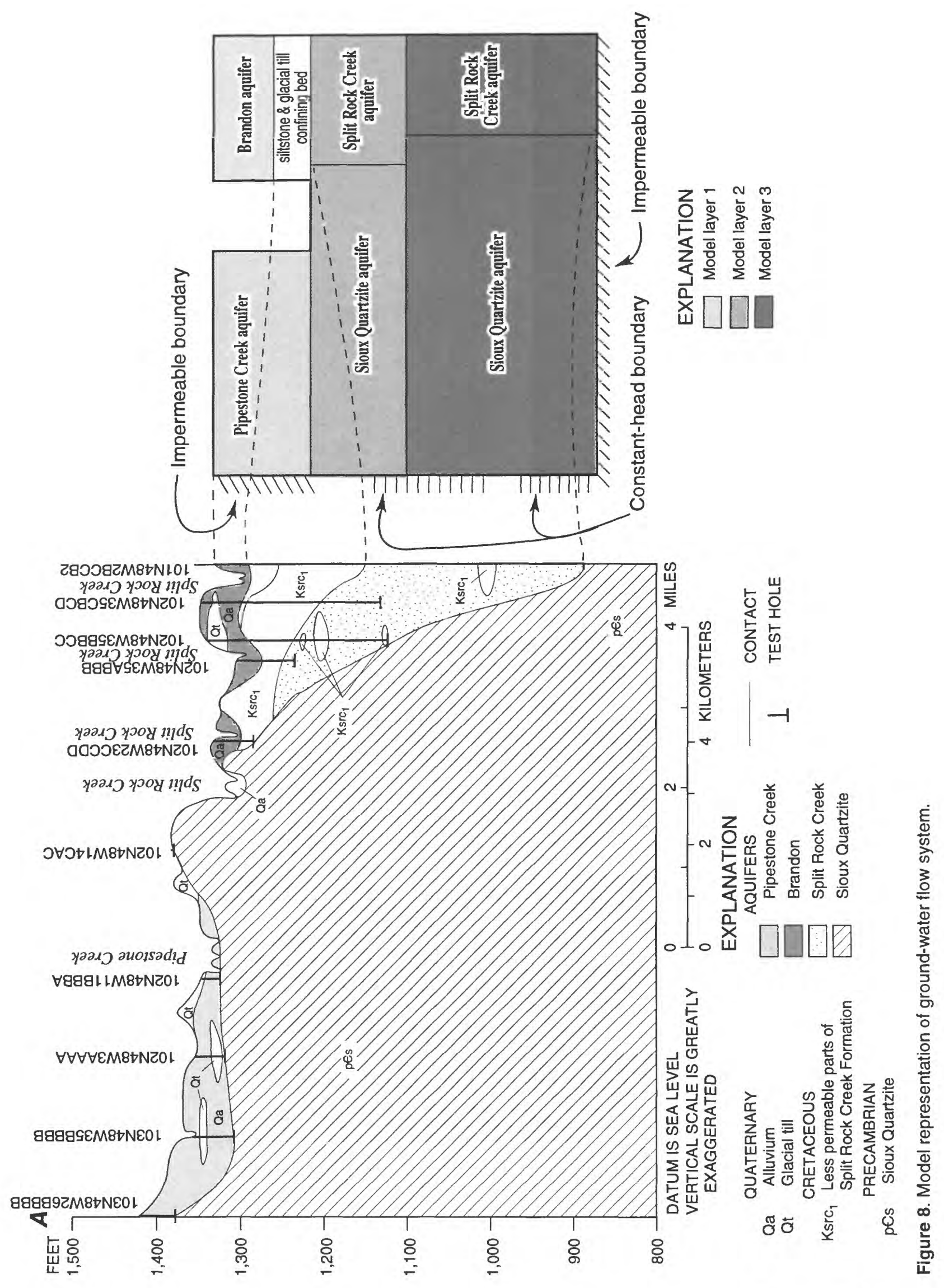




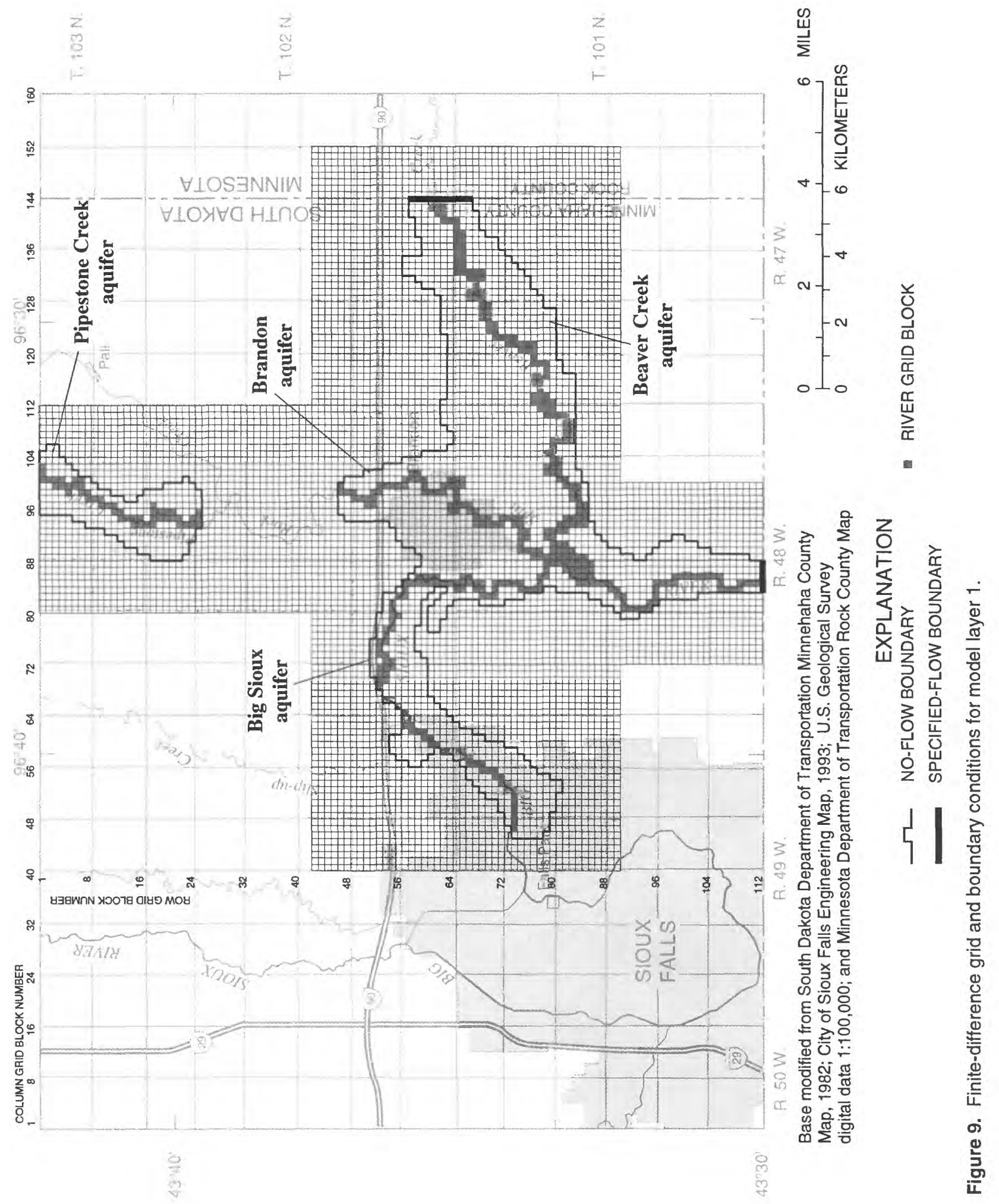




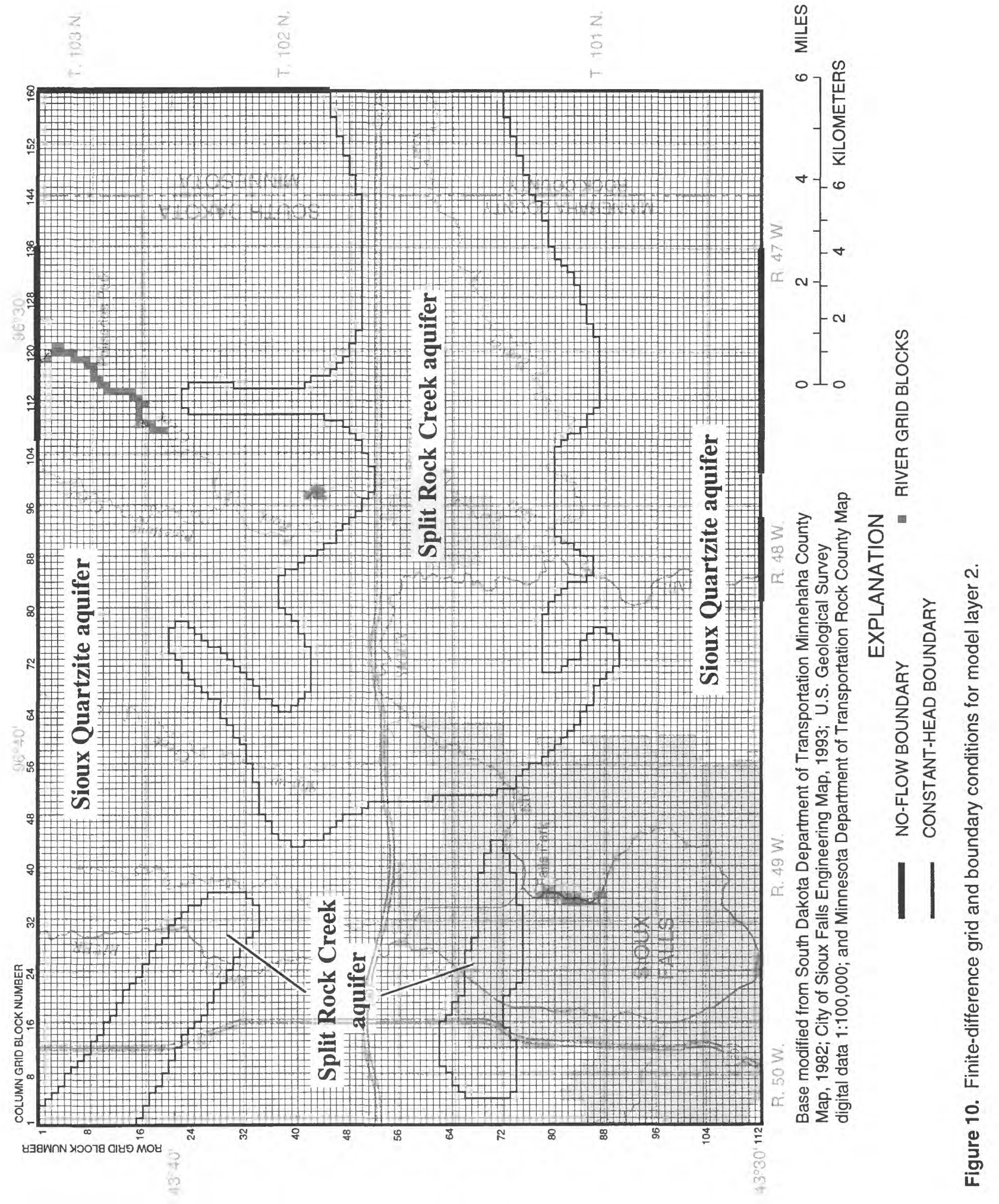




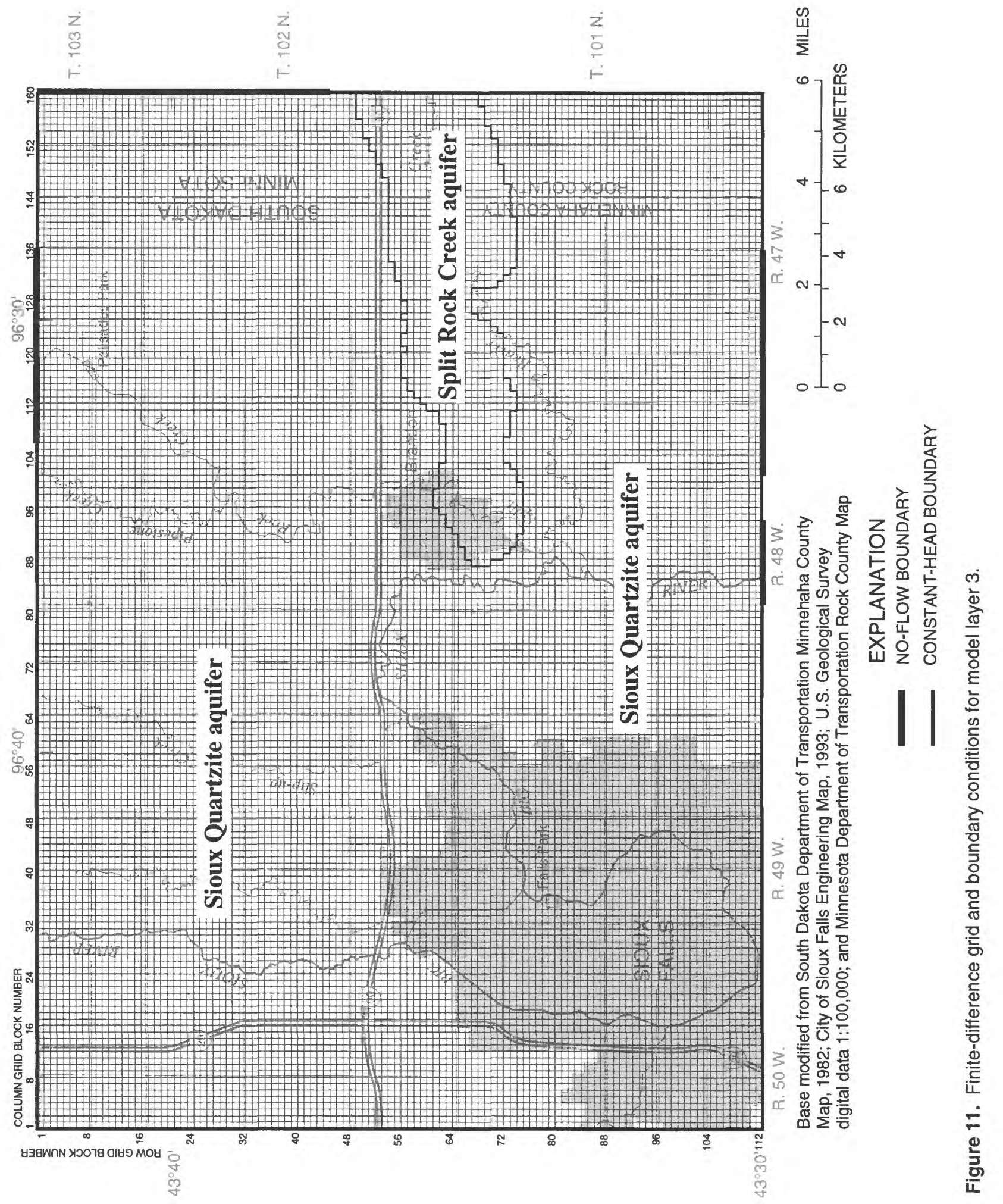


The active model grid blocks were extended outward to the edge of the study area to include the arms of the Split Rock Creek aquifer (fig. 3). The hydraulic connection of these arms to the Sioux Quartzite provided a method of calibrating the model representation of the surrounding Sioux Quartzite. The hydraulic heads measured in the arms were assumed to be representative of ground-water flow in the Sioux Quartzite.

Layer 1 represents the Brandon aquifer and parts of the Big Sioux, Pipestone Creek, and Beaver Creek aquifers (fig. 9). Layer 2 represents the part of the Split Rock Creek aquifer above an altitude of $1,100 \mathrm{ft}$ and the upper part of the surrounding high areas of the Sioux Quartzite aquifer (fig. 10). Layer 3 represents the deeper part of the Sioux Quartzite aquifer and the deeper part of the Split Rock Creek aquifer where the altitude of the Sioux Quartzite surface (fig. 2) is below $1,100 \mathrm{ft}$ (fig. 11).

Confining bed 1 represents the glacial till, fractured siltstone, and shale between the alluvial aquifers and the Split Rock Creek aquifer. Where the confining bed was unweathered glacial till or shale, the vertical hydraulic conductivity was assumed to be zero. Vertical flow between (1) parts of the alluvial aquifers, layer 1, and the Sioux Quartzite aquifer, layer 2; (2) the upper part of the Sioux Quartzite aquifer, layer 2, and the lower part of the Sioux Quartzite aquifer, layer 3; (3) the Split Rock Creek aquifer, layer 2, and Sioux Quartzite aquifer, layer 3; and (4) the two parts of the Split Rock Creek aquifer represented in layer 2 and layer 3, was a function of the horizontal hydraulic conductivity of the aquifer layers and an assumed verticalto-horizontal anisotropy.

\section{Boundary Conditions}

No-flow boundaries were used at the perimeter of the alluvial aquifers bordered by glacial till (fig. 9). The area of the Big Sioux aquifer at the south boundary of the study area (fig. 9) was represented as a specified outflow of $0.05 \mathrm{ft}^{3} / \mathrm{s}$. Lindgren and Niehus (1992) interpreted the flow direction in the Big Sioux aquifer at the south edge of the study area as being predominately parallel to the boundary, converging on the Big Sioux River; therefore, the downvalley gradient at the boundary was primarily accounted for by headdependent leakage at the grid blocks representing the river. The east boundary of the Beaver Creek aquifer was represented as specified inflow, at the MinnesotaSouth Dakota border, of $0.83 \mathrm{ft}^{3} / \mathrm{s}$ (Lindgren and Niehus, 1992).
Boundary conditions of layer 2 and layer 3 (figs. 10 and 11) at the perimeter, assumed to be identical, represent the continuation of the Sioux Quartzite aquifer or the Split Rock Creek aquifer at the edge of the study area. No-flow boundaries were used where the flow direction was parallel to the boundary or where a flow divide existed (fig. 6). Constant-head grid blocks were used to represent the boundary at the perimeter of the layer where inflow or outflow occurred (fig. 6).

\section{Representation of Hydraulic Properties}

The range of hydraulic conductivity used for model studies of adjacent alluvial aquifers was 200 to $450 \mathrm{ft} / \mathrm{d}$ (Hansen, 1988; Ohland, 1990). Hydraulic conductivities used for this model for the alluvial aquifers ranged from 200 to $300 \mathrm{ft} / \mathrm{d}$.

The altitude of the bottom of the alluvial aquifers used to calculate transmissivity by multiplying the saturated thickness by the hydraulic conductivity, was determined from test-hole logs. The bottom altitude for grid blocks with no test-hole logs was interpolated between known bottom altitudes.

Transmissivity assigned to the Split Rock Creek aquifer (fig. 12) was determined from correlations between aquifer-test results and test-hole logs. The thickness of the porous media and an estimate of hydraulic conductivity based on the aquifer tests were used to calculate a transmissivity at each grid block with one or more test-hole logs. Transmissivity at grid blocks without a test-hole log was interpolated between the grid blocks with calculated values. Transmissivity values ranged from 200 to $12,700 \mathrm{ft}^{2} / \mathrm{d}$ with a mean of $2,100 \mathrm{ft}^{2} / \mathrm{d}$. Where the Split Rock Creek aquifer was represented in layer 3 , the transmissivity shown in fig. 12 was distributed between aquifer layers 2 and 3 based on relative thicknesses.

Transmissivity assigned to the Sioux Quartzite aquifer was based on the range of transmissivity described by the seven aquifer tests in the Sioux Quartzite aquifer east of the study area. Transmissivity in layer 2 ranged from 10 to $1,800 \mathrm{ft}^{2} / \mathrm{d}$ with a mean of $160 \mathrm{ft}^{2} / \mathrm{d}$. The higher values represented areas of the Sioux Quartzite aquifer, which included overlying fractured siltstone near the Big Sioux aquifer in the south-central part of the study area. An additional mechanism of flow in the area around the Big Sioux aquifer includes lateral flow in lenses of the Split Rock 


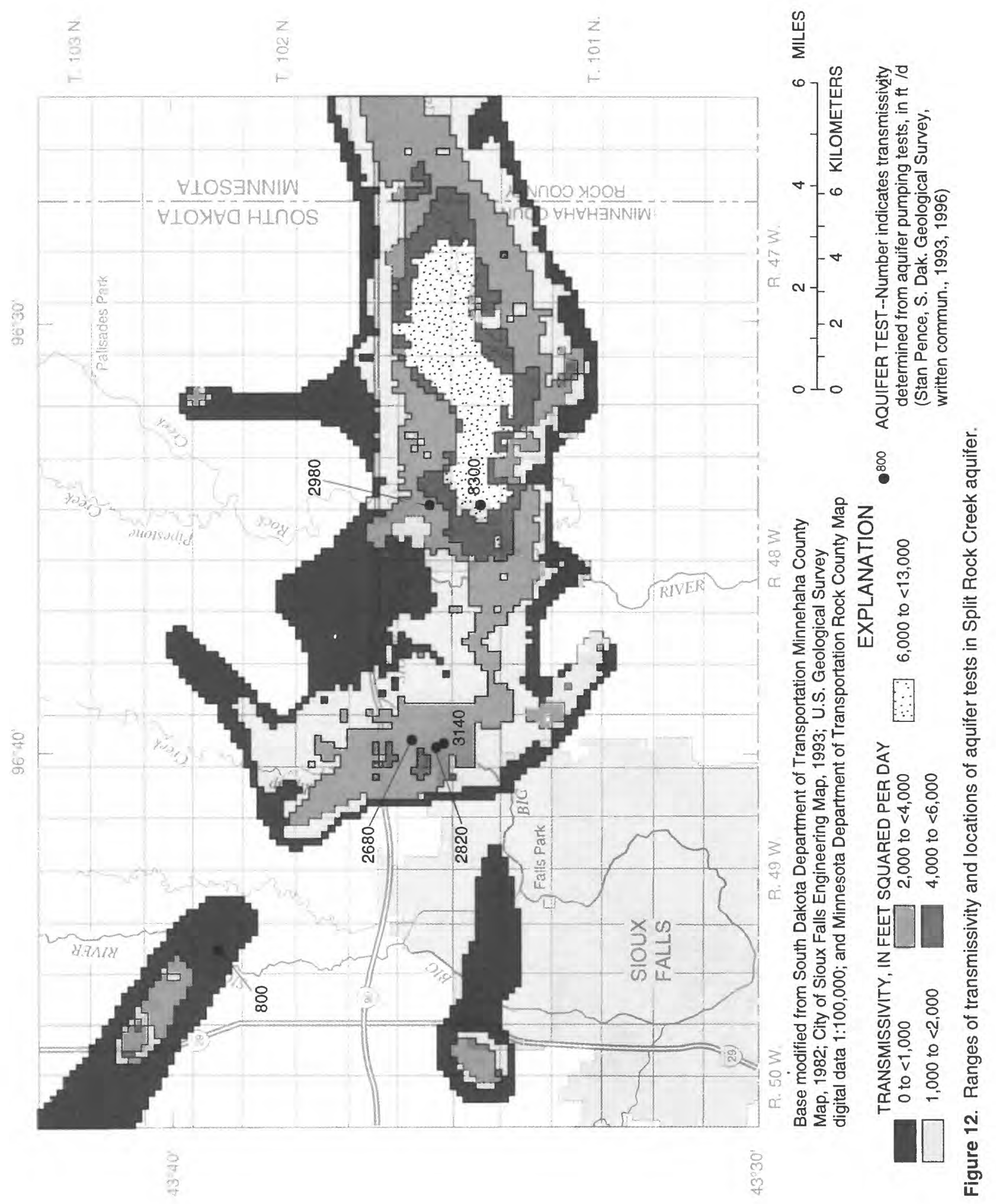


Creek Formation hydraulically connected directly to the Big Sioux aquifer. These permeable lenses were not significant enough to be described as part of the Split Rock Creek aquifer; however, increased transmissivity was assigned to layer 2 . Transmissivity in layer 3 ranged from 10 to $310 \mathrm{ft}^{2} / \mathrm{d}$ with a mean of $60 \mathrm{ft}^{2} / \mathrm{d}$.

The storage coefficient assigned to the Split Rock Creek aquifer was 0.00026 . The storage coefficient assigned to the Sioux Quartzite aquifer was assumed to be 0.0001 because no measured data was available. The altitude of the top of the Split Rock Creek aquifer and the Sioux Quartzite aquifer was calculated from test-hole logs. Where insufficient data were available, the interpretation shown in figure 2 was used as a guide. In areas where the head was below the top of the aquifer, the storage coefficient for the grid block was converted to an assumed specific yield of 0.2 to simulate water-table conditions. The change in saturated thickness at these grid blocks was assumed negligible in relation to the thickness of the aquifer; therefore, a constant transmissivity was used at grid blocks converting to water-table conditions. A specific yield of 0.2 was also used for the alluvial aquifers.

The model calculates vertical flow between model layers by multiplying the area of the grid block by the difference in head between the two model layers and the vertical conductance. Vertical conductance is the weighted vertical conductance (vertical hydraulic conductivity of the unit divided by the sum of half thickness of each unit) of the aquifer layers and the confining bed or of the two vertically adjacent aquifers. When the vertical hydraulic conductivity of the confining bed is much less than the vertical hydraulic conductivity of the aquifer, the vertical conductance (units of time $^{-1}$ ) is the vertical hydraulic conductivity of the confining bed divided by the thickness of the confining bed. When the vertical hydraulic conductivity of the confining bed is high or the confining bed is absent, the vertical conductance of the aquifer is included and weighted in the calculation of the vertical conductance assigned to the grid block.

The vertical conductance assigned to the fractured siltstone separating the Split Rock Creek aquifer from the overlying alluvial aquifers (fig. 13) ranged from 0.00002 to $0.006(\mathrm{ft} / \mathrm{d}) / \mathrm{ft}$ with a mean of $0.002(\mathrm{ft} / \mathrm{d}) / \mathrm{ft}$. Where the fractured siltstone included significant layers of shale, the vertical hydraulic conductivity was assumed to be zero. Assuming an averaged thickness of fractured siltstone of $45 \mathrm{ft}$, the vertical hydraulic conductivity of the siltstone ranged from 0.0009 to $0.27 \mathrm{ft} / \mathrm{d}$ with a mean of $0.09 \mathrm{ft} / \mathrm{d}$. The range of plausible values was estimated from aquifer tests and the thickness of the fractured siltstone.

The range of vertical conductance between the alluvial aquifers overlying the Sioux Quartzite (fig. 13) was estimated from horizontal hydraulic conductivity used for the Sioux Quartzite, with vertical anisotropy assumed equal to 1 because of the block-like fracturing pattern of exposed Sioux Quartzite. The vertical conductance ranged from 0.00002 to $0.008(\mathrm{ft} / \mathrm{d}) / \mathrm{ft}$ with a mean value of $0.003(\mathrm{ft} / \mathrm{d}) / \mathrm{ft}$ and the lower values assigned to areas with glacial till within the alluvial aquifers.

The mean vertical conductance between the parts of layer 2 and layer 3 representing the upper and lower areas of the Sioux Quartzite aquifer was $0.002(\mathrm{ft} / \mathrm{d}) / \mathrm{ft}$ and the parts of layer 2 and layer 3 representing the Split Rock Creek aquifer and the lower Sioux Quartzite aquifer was $0.008(\mathrm{ft} / \mathrm{d}) / \mathrm{ft}$. The vertical conductance between the parts of layer 2 and layer 3 representing the deep part of the Split Rock Creek aquifer was calculated from hydraulic conductivity, the thickness, and a vertical anisotropy ratio of 1:5. The vertical-to-horizontal conductance ranged from 0.03 to $0.89(\mathrm{ft} / \mathrm{d}) / \mathrm{ft}$ with a mean of $0.15(\mathrm{ft} / \mathrm{d}) / \mathrm{ft}$.

\section{Representation of Recharge and Discharge}

Average annual precipitation for the simulated steady-state period, was 22.25 in. An annual recharge rate of $5.3 \mathrm{in} / \mathrm{yr}$ was estimated for average conditions (1961-90) with annual precipitation averaging $23.86 \mathrm{in} / \mathrm{yr}$. Therefore, a steady-state recharge rate of $5.0 \mathrm{in} / \mathrm{yr}$ was used for the alluvial aquifers. A recharge rate of $4.0 \mathrm{in} / \mathrm{yr}$ was assigned to the Sioux Quartzite aquifer outcrop areas or where the aquifer is overlain by thin layers of glacial till or alluvium. Areas surrounding the outcrops were assigned lesser amounts of recharge based on the thickness of the overlying glacial till or alluvium. The steady-state recharge rate assigned to the Sioux Quartzite recharge areas (fig. 14) ranged from 1.0 to $4.0 \mathrm{in} / \mathrm{yr}$ with a mean value of $3.0 \mathrm{in} / \mathrm{yr}$. The recharge rate for transient simulations was distributed as described in table 1.

Although the Split Rock Creek aquifer is not directly connected to the overlying streams, the boundary conditions represented by the overlying alluvial aquifers and the Sioux Quartzite aquifer are influenced by hydraulic connections to streams. Stream leakage to and from the overlying alluvial aquifers and Sioux 


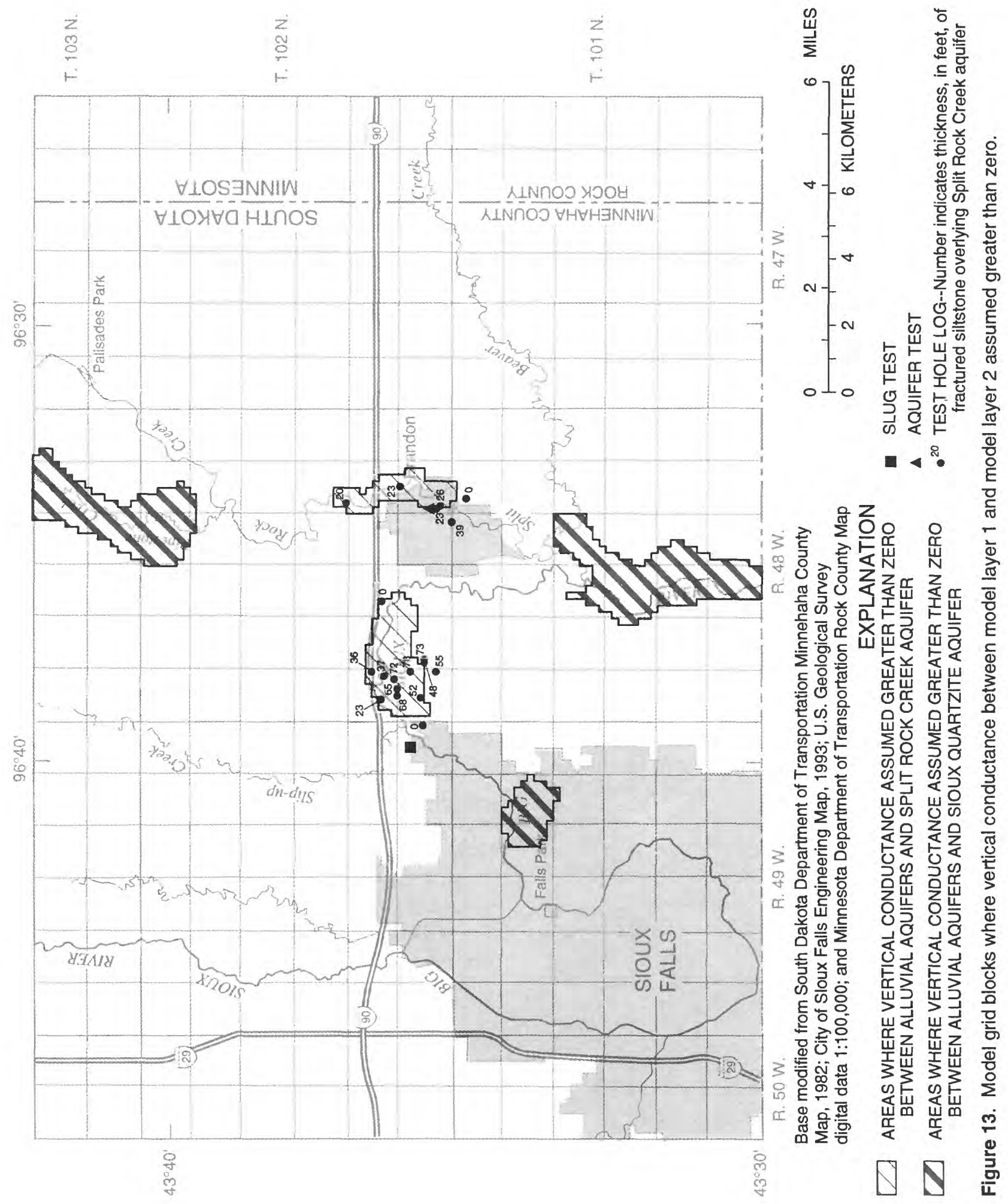




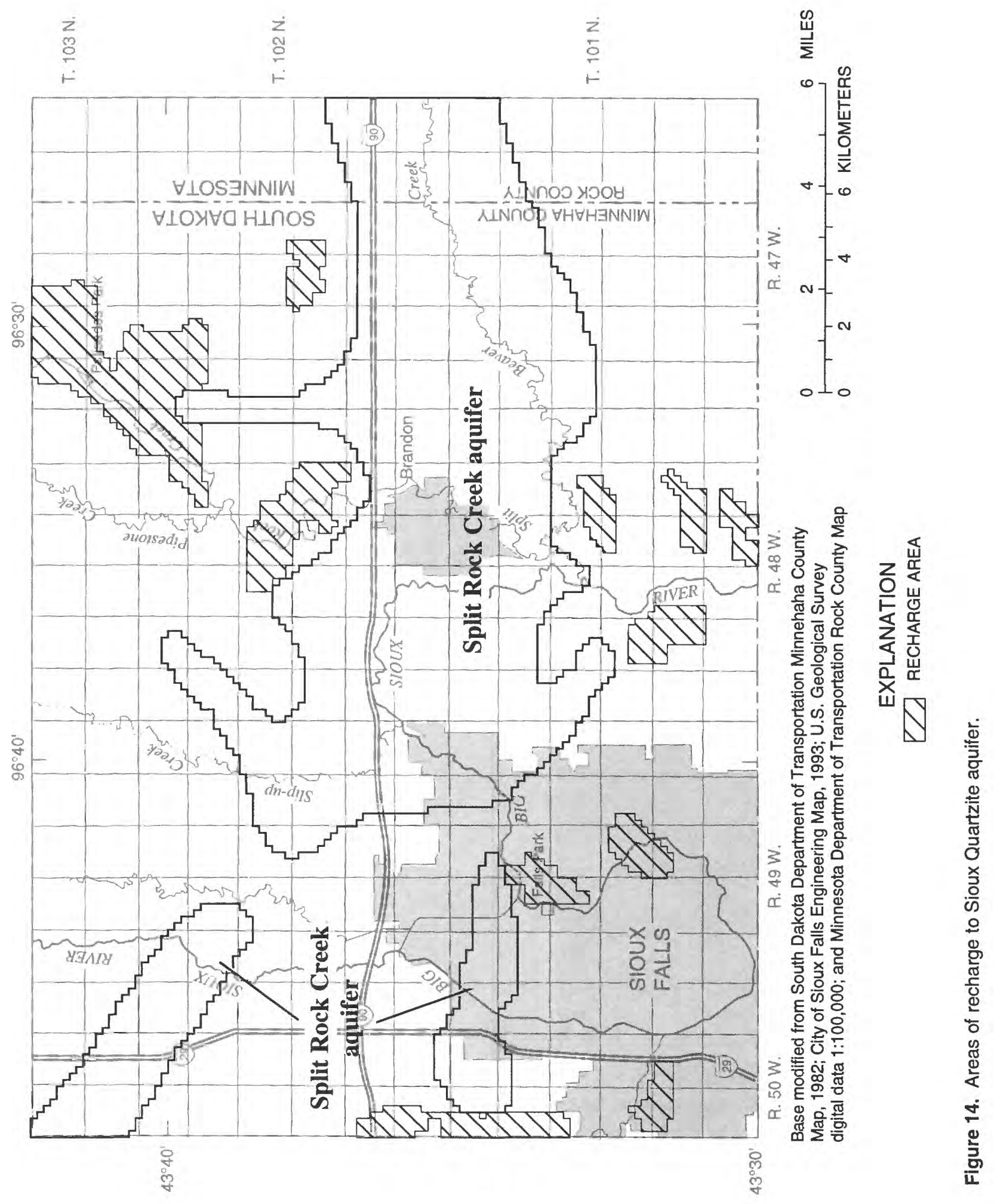


Quartzite aquifer was simulated by the river package of the model program (McDonald and Harbaugh, 1988). The model calculates stream leakage by multiplying the difference in head between the stream and the aquifer by the streambed conductance. Streambed conductance was estimated from the streambed hydraulic conductivity, thickness, width, and length represented in each grid block.

A uniform vertical hydraulic conductivity of $0.05 \mathrm{ft} / \mathrm{d}$ was used in calculating streambed conductance for this study based on the previously described studies of hydraulic conductivity of streambed material in nearby streams. The area of the streambed was calculated from topographic maps and the thickness of the streambed sediment was assumed to be $1 \mathrm{ft}$. The stream-altitude data were determined from topographic maps and correlated to the gage-height record for the streamflow-gaging station at the Big Sioux River at North Cliff Avenue, at Sioux Falls, S. Dak. (U.S. Geological Survey station number 06482020). For transient simulations, the stream altitude was correlated to the average gage height for the stress period at the North Cliff Avenue gaging station.

Simulated evapotranspiration at the maximum rate applied to layer 1 and the part of layer 2 not overlain by layer 1 occurred when the water level in the aquifer was at land surface. The evapotranspiration rate was decreased linearly with the depth of the simulated water level below the land surface, to zero at the extinction depth. The extinction depth, estimated from the depth of penetration of plant roots, was assigned as $5 \mathrm{ft}$ for most of the area. An extinction depth of $10 \mathrm{ft}$ was used at model grid blocks traversed by simulated streams, based on the deep root system of phreatophytes along the stream.

Evapotranspiration for steady-state and transient simulations was based on 70 percent of the pan evaporation recorded for the stress period. No evapotranspiration was assigned for transient simulations during the months of December, January, and February due to frozen soil conditions. The maximum monthly pan evaporation for the transient simulations was 9.5 in. in July 1991, and the minimum monthly pan evaporation was 2.0 in. for November 1991. Assigned discharge from pumping was based on the pumping rates summarized in table 2 .

\section{Model Calibration}

Model calibration was accomplished by varying the model-input parameters within plausible ranges to produce the best fit between simulated and observed hydraulic heads in the Split Rock Creek aquifer. Three simulations, (1) steady-state, (2) transient quarterly, 1990-92, and (3) transient monthly, 1993, were analyzed to determine the best combination of modelinput parameters. Closure criteria for numerical solutions to be complete was less than $0.002 \mathrm{ft}$ average change in head between iterations. Percent discrepancy between inflow and outflow in total water budgets was less than 1 percent.

\section{Steady-State Simulation}

Steady-state simulation represents an equilibrium condition in which no change in aquifer storage occurs when the average of aquifer stresses for the period are applied. Steady-state simulation of the average of aquifer stresses for 1985-89 was made to calibrate the model to near-average conditions prior to significant pumping from the aquifer.

The average of the difference between the simulated and observed potentiometric heads at 23 wells was $-0.4 \mathrm{ft}$, and the average absolute difference was $2.2 \mathrm{ft}$. The maximum positive difference was $4.2 \mathrm{ft}$ and the maximum negative difference was $5.7 \mathrm{ft}$. Comparison of simulated and observed hydraulic head (fig. 15) shows similar directions of flow and gradients.

Water budgets for the aquifers simulated for the steady-state condition (table 3) show inflow of $1.8 \mathrm{ft}^{3} / \mathrm{s}$ to the main body of the Split Rock Creek aquifer from the Sioux Quartzite aquifer. Inflow of $0.3 \mathrm{ft}^{3} / \mathrm{s}$ from constant-head boundaries represents subsurface flow from outside the modeled area.

Outflow of $0.9 \mathrm{ft}^{3} / \mathrm{s}$ occurred to the Sioux Quartzite along the south edge of the Split Rock Creek aquifer where the Big Sioux aquifer overlies the Sioux Quartzite and along the southeast edge of the Split Rock Creek aquifer where the Sioux Quartzite slopes towards the south and overlies the Dakota Formation. Vertical outflow of $0.6 \mathrm{ft}^{3} / \mathrm{s}$ to the Big Sioux aquifer and $0.6 \mathrm{ft}^{3} / \mathrm{s}$ to the Brandon aquifer accounts for the remaining outflow from the Split Rock Creek aquifer.

The water budget for the Sioux Quartzite aquifer indicates that 85 percent of the inflow was recharge from precipitation and inflow from constant-head boundaries. Flow to the Split Rock Creek aquifer accounts for 24 percent of the outflow. 


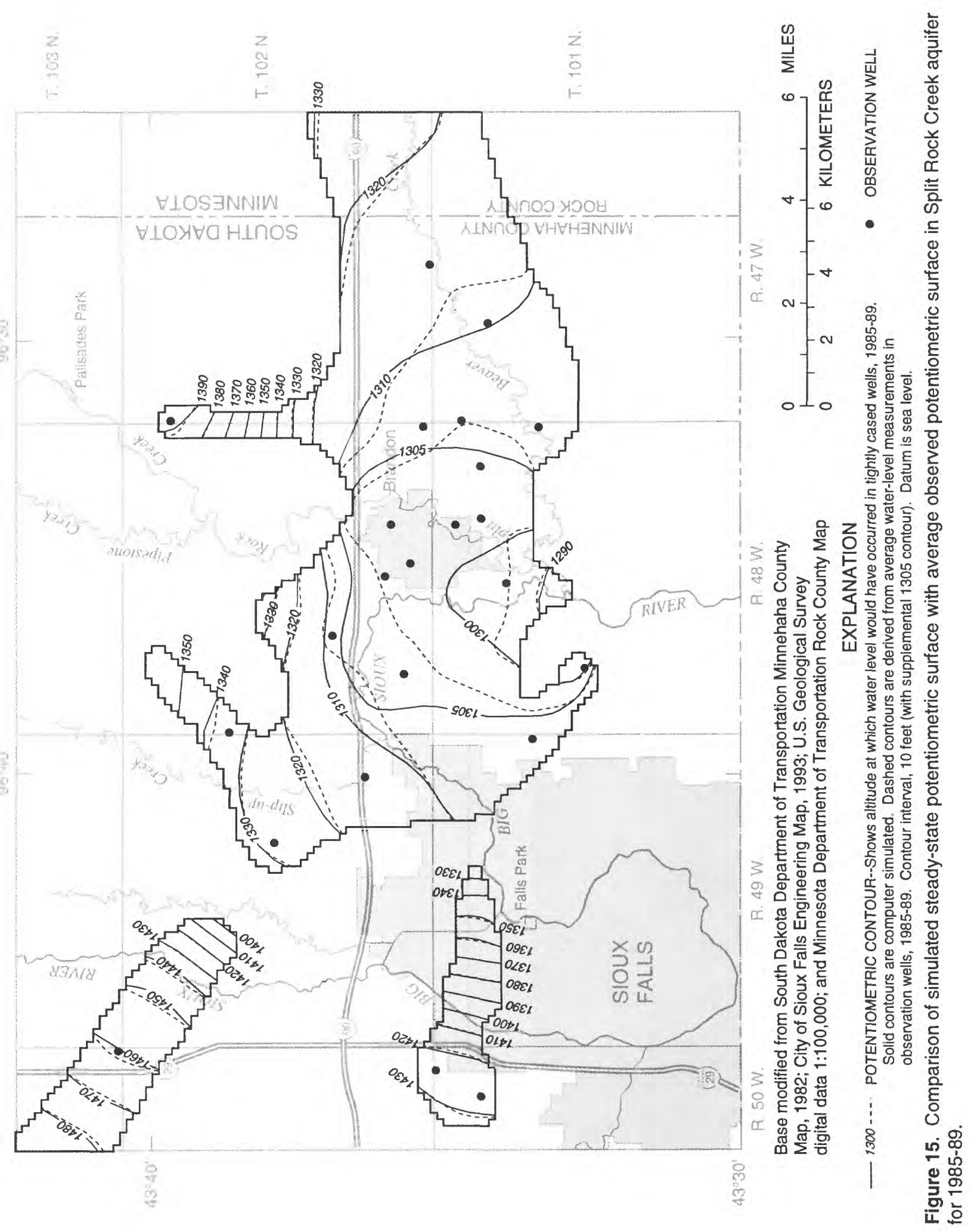




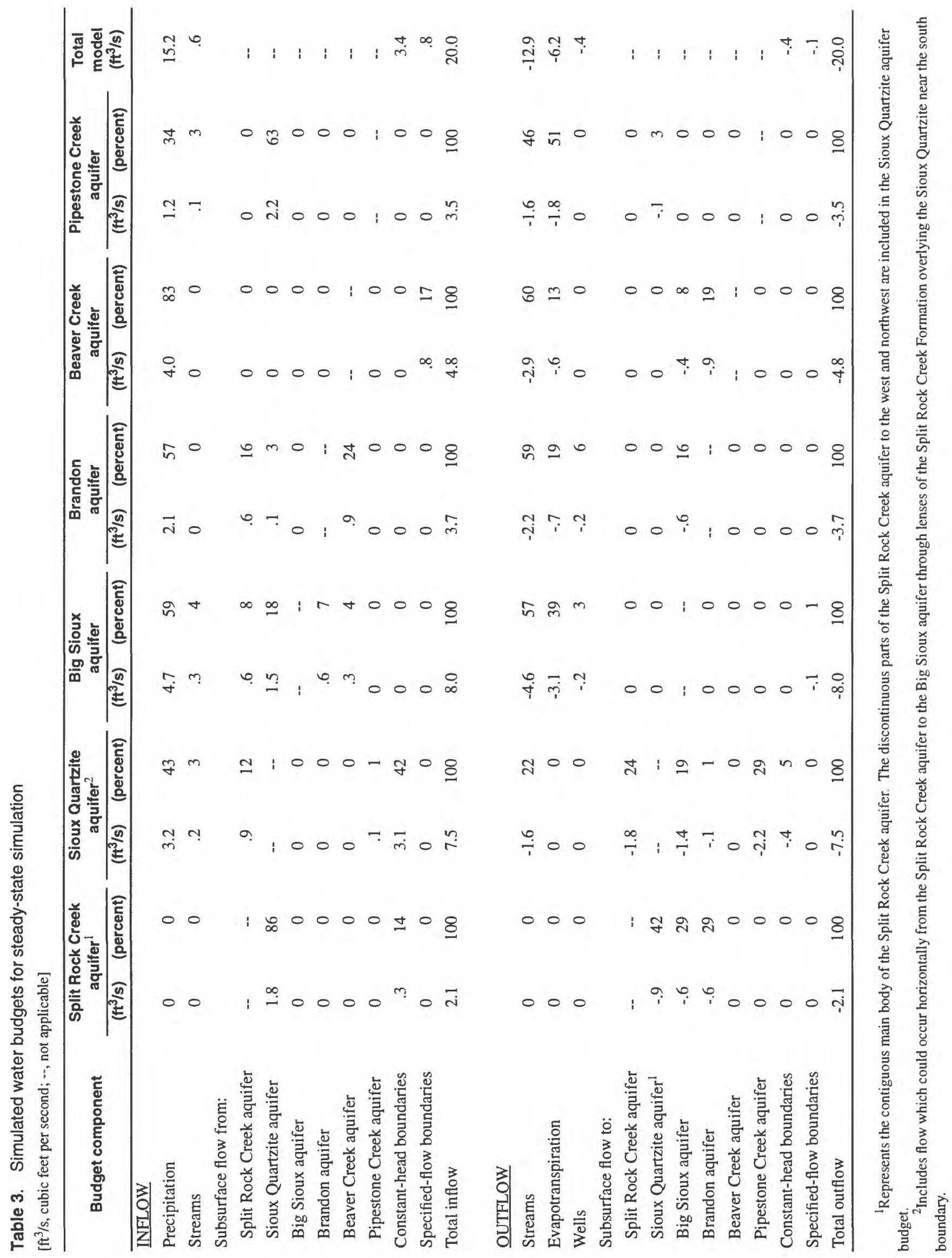


Water budgets for the alluvial aquifers show that upward flow to the Big Sioux aquifer from the Split Rock Creek aquifer contributes 8 percent of the inflow to the Big Sioux aquifer. Upward flow to the Brandon aquifer from the Split Rock Creek aquifer contributes 16 percent of the inflow to the Brandon aquifer. Infiltration of precipitation provides most of the inflow to the alluvial aquifers whereas most of the outflow is to streams and evapotranspiration. The Beaver Creek aquifer contributes inflow to the Big Sioux aquifer and the Brandon aquifer. The Brandon aquifer also contributes inflow to the Big Sioux aquifer.

\section{Sensitivity Analysis}

A sensitivity analysis examines the response of the calibrated steady-state model to changes in boundary conditions, hydraulic properties, and aquifer stresses. The response provides (1) a guide in using the model to refine model-input parameters during the calibration process, (2) a guide for additional data that could be collected to improve the model, and (3) a sense of the model uncertainty.

The effect of constant-head representation of the Sioux Quartzite aquifer and the Split Rock Creek aquifer at the perimeter of the model in layers 2 and 3 was analyzed by lowering and raising the constant head by $5 \mathrm{ft}$ and calculating the change in simulated average arithmetic difference and average absolute difference in hydraulic head at the 19 grid blocks with measured hydraulic heads in the central part of the Split Rock Creek aquifer. Comparison only to the 19 wells in the central part of the aquifer was made because the remaining 4 observation wells were close to the model boundary. Lowering the constant heads in layers 2 and 3 by $5 \mathrm{ft}$ produced an average arithmetic difference of $-1.5 \mathrm{ft}$ (a change of $-1.1 \mathrm{ft}$ ) and an average in the absolute difference of $2.8 \mathrm{ft}$ (a change of $0.6 \mathrm{ft}$ ). Raising the constant heads in layers 2 and 3 by $5 \mathrm{ft}$ produced an average arithmetic difference of $+0.3 \mathrm{ft}$ (a change of $+0.7 \mathrm{ft}$ ) and an average in the absolute difference of $2.3 \mathrm{ft}$ (a change of $+0.1 \mathrm{ft}$ ). Although error introduced in the model by incorrectly interpreting the head assigned to the constant-head boundaries influenced model calibration, moving the boundaries back from the area of interest reduced the effect compared to initial simulations which established boundary conditions at the perimeter of the Split Rock Creek aquifer.

Sensitivity of the steady-state model to hydraulic properties and aquifer stresses was analyzed by increasing and decreasing by 50 percent: (1) Recharge to the Sioux Quartzite aquifer, (2) vertical hydraulic conductivity between the Split Rock Creek aquifer and overlying alluvial aquifers, (3) recharge to the alluvial aquifers, (4) transmissivity of the Sioux Quartzite aquifer, (5) transmissivity of the Split Rock Creek aquifer, and (6) streambed conductance. Average arithmetic and absolute differences between the simulated and observed heads (table 4) showed the most

Table 4. Summary of sensitivity analysis results for the steady-state model

\begin{tabular}{|c|c|c|}
\hline Steady-state simulation & $\begin{array}{l}\text { Average difference } \\
\text { between simulated } \\
\text { and observed } \\
\text { hydraulic heads } \\
\text { (feet) }\end{array}$ & $\begin{array}{l}\text { Average absolute } \\
\text { difference between } \\
\text { simulated and observed } \\
\text { hydraulic heads } \\
\text { (feet) }\end{array}$ \\
\hline Steady-state model solution & -0.4 & 2.2 \\
\hline Recharge to Sioux Quartzite aquifer increased by 50 percent & 1.3 & 2.8 \\
\hline Recharge to Sioux Quartzite aquifer decreased by 50 percent & -2.2 & 3.3 \\
\hline $\begin{array}{l}\text { Vertical hydraulic conductivity between Split Rock Creek aquifer and over- } \\
\text { lying alluvial aquifers increased by } 50 \text { percent }\end{array}$ & -.8 & 2.5 \\
\hline $\begin{array}{l}\text { Vertical hydraulic conductivity between Split Rock Creek aquifer and over- } \\
\text { lying alluvial aquifers decreased by } 50 \text { percent }\end{array}$ & .3 & 2.2 \\
\hline Recharge to alluvial aquifers increased by 50 percent & -.1 & 2.2 \\
\hline Recharge to alluvial aquifers decreased by 50 percent & -.7 & 2.4 \\
\hline Transmissivity of Sioux Quartzite aquifer increased by 50 percent & .1 & 2.6 \\
\hline Transmissivity of Sioux Quartzite aquifer decreased by 50 percent & .4 & 3.7 \\
\hline Transmissivity of Split Rock Creek aquifer increased by 50 percent & .9 & 2.5 \\
\hline Transmissivity of Split Rock Creek decreased by 50 percent & .8 & 2.7 \\
\hline Streambed conductance increased by 50 percent & .6 & 2.3 \\
\hline Streambed conductance decreased by 50 percent & .1 & 2.1 \\
\hline
\end{tabular}


sensitivity to recharge to the Sioux Quartzite aquifer followed by vertical hydraulic conductivity between the Split Rock Creek aquifer and the overlying alluvial aquifers and transmissivity of the Split Rock Creek aquifer.

The steady-state model was least sensitive to transmissivity in the Sioux Quartzite aquifer and streambed conductance. Some localized areas showed more response to changes in particular parameters than indicated by the averages listed in table 4 . Vertical conductivity had more effect on the simulated head near the areas with vertical leakage than elsewhere. Transmissivity of the Sioux Quartzite had more influence in the western part of the Split Rock Creek aquifer than elsewhere. The model parameters selected for the calibrated model were based on the following transient simulations as well as the steady-state simulation.

\section{Transient Simulations}

Transient simulations, which calculate changes in aquifer storage with respect to time, were used to analyze the model response to variations in aquifer stresses. Transient quarterly simulations included a period with below-normal precipitation in 1990 and above-normal precipitation in 1991-93. Pumping from the Split Rock Creek aquifer began at the two Sioux Falls municipal wells in the last quarter of 1990. The additional pumping at two Sioux Falls municipal wells was discontinued in June and July 1993 due to flood conditions. Annual precipitation during the 1993 monthly simulations was 12 in. above normal.

Constant-head boundaries with inflow as determined in the steady-state simulation were changed to specified-flow boundaries equal to the flow calculated in the steady-state simulation. Comparison of hydrographs on each side of the boundary in the arms at the northwest corner of the model showed a relatively stable gradient across the boundary with changing stresses. The specified inflow of $3.4 \mathrm{ft}^{3} / \mathrm{s}$ allowed an analysis of stresses without inducing unreasonable inflow at the model boundaries in subsequent simulations.

Table 5. Comparison between simulated and observed hydraulic heads in the Split Rock Creek aquifer

\begin{tabular}{|c|c|c|c|c|}
\hline Simulation sequence & Simulation & $\begin{array}{c}\text { Average difference } \\
\text { between simulated } \\
\text { and observed } \\
\text { hydraulic heads } \\
\text { (feet) }\end{array}$ & $\begin{array}{c}\text { Average absolute } \\
\text { difference between } \\
\text { simulated and observed } \\
\text { hydraulic heads } \\
\text { (feet) }\end{array}$ & $\begin{array}{l}\text { Number } \\
\text { of wells }\end{array}$ \\
\hline Steady-state & $1985-89$ & -0.4 & 2.2 & 23 \\
\hline \multirow[t]{12}{*}{ Transient quarterly } & December 1989-February 1990 & 1.0 & 3.0 & 27 \\
\hline & March 1990-May 1990 & 3.4 & 4.1 & 27 \\
\hline & June 1990-August 1990 & 3.4 & 4.0 & 27 \\
\hline & September 1990-November 1990 & 2.8 & 3.9 & 27 \\
\hline & December 1990-February 1991 & 1.3 & 4.1 & 30 \\
\hline & March 1991-May 1991 & 3.0 & 5.8 & 32 \\
\hline & June 1991-August 1991 & 4.5 & 5.9 & 32 \\
\hline & September 1991-November 1991 & 3.7 & 5.5 & 32 \\
\hline & December 1991-February 1992 & 2.0 & 4.1 & 32 \\
\hline & March 1992-May 1992 & 3.3 & 5.2 & 30 \\
\hline & June 1992-August 1992 & 2.1 & 5.1 & 34 \\
\hline & September 1992-November 1993 & 1.4 & 4.7 & 34 \\
\hline \multirow[t]{8}{*}{ Transient monthly } & January 1993 & -.6 & 4.4 & 30 \\
\hline & February 1993 & -.3 & 4.0 & 31 \\
\hline & March 1993 & .1 & 4.3 & 32 \\
\hline & April 1993 & .3 & 3.8 & 34 \\
\hline & May 1993 & 1.7 & 5.5 & 30 \\
\hline & August 1993 & .9 & 4.8 & 31 \\
\hline & October 1993 & .4 & 5.2 & 36 \\
\hline & November 1993 & .7 & 5.3 & 36 \\
\hline
\end{tabular}


Steady-state and transient calibration results summarized in table 5 show the steady-state and transient monthly simulation sequences best matching observed values. The average difference between simulated and observed heads was $-0.4 \mathrm{ft}$ for the steady-state simulation, $+2.7 \mathrm{ft}$ for the transient quarterly simulations, and $+0.4 \mathrm{ft}$ for the transient monthly simulations. The location of the 23 wells used for the steady-state simulation are shown on figure 15 and the locations of the 36 observation wells used in transient simulations are listed in table 6 . The number of wells with observed hydraulic heads varied with each transient simulation period.

The simulated head for the transient quarterly simulations averaged consistently higher than the observed head; however, an analysis of the individual wells indicated that a large part of the discrepancy occurred at observation wells in the arms. When the five observation wells in the arms were eliminated from the comparison for the transient quarterly simulation, the average difference between the simulated and observed head was $+1.4 \mathrm{ft}$ compared to $+2.7 \mathrm{ft}$, and the average absolute difference was $3.4 \mathrm{ft}$ compared to $4.6 \mathrm{ft}$. When the five observation wells in the arms were eliminated from the comparison for the transient monthly simulation, the average difference between the simulated and observed head was $-0.1 \mathrm{ft}$ compared to $0.4 \mathrm{ft}$, and the average absolute difference was $4.5 \mathrm{ft}$ compared to $4.7 \mathrm{ft}$.

The close fit of the steady-state simulation to the observed head at the wells in the arms was used as a basis for calibrating the areas near the boundaries. The larger head differences in the arms in the transient quarterly simulations were attributed to the effect of boundary conditions.

Hydrographs comparing simulated and observed heads (fig. 16) at representative locations in the three model layers show generally similar declines during below-average precipitation and recovery during above-average precipitation during 1991-93. The Big Sioux and Sioux Quartzite aquifer wells were not part of the calibration criteria; however, the simulated and observed heads were compared to assess the representation of the aquifers as boundary conditions for the Split Rock Creek aquifer. The effect of averaging stress over the length of the stress periods was evident as the changes in simulated heads changed less abruptly than observed heads; however, the pattern described by the simulated values generally compares well with the observed values.
Table 6. Split Rock Creek aquifer observation wells used for transient simulations

\begin{tabular}{|c|c|c|}
\hline $\begin{array}{l}\text { South Dakota } \\
\text { Geological Survey } \\
\text { well identifier }\end{array}$ & $\begin{array}{l}\text { Observation } \\
\text { wells also used } \\
\text { in steady-state } \\
\text { simulation }\end{array}$ & Local well number \\
\hline SRC-1A & $\mathrm{x}$ & 101N47W 8AAAA \\
\hline SRC-2A & $\mathrm{x}$ & $101 N 48 W 1 C C C D$ \\
\hline SRC-4A & $\mathrm{x}$ & 101N48W 2CCCC \\
\hline SRC-7A & $\mathrm{x}$ & 101N48W 9ADDD2 \\
\hline SRC-8 & $\mathrm{x}$ & 101N48W13AAAA \\
\hline SRC-9 & $\mathrm{x}$ & 101N48W17CDCC \\
\hline SRC-10 & $\mathrm{x}$ & 101N49W12DDDA \\
\hline SRC-11A & $\mathrm{x}$ & 101N50W 1ABBB1 \\
\hline SRC-12A & $\mathrm{x}$ & 101N50W $1 \mathrm{CCCC} 1$ \\
\hline SRC-13 & $\mathrm{x}$ & $102 \mathrm{~N} 47 \mathrm{~W} 6 \mathrm{CCCC}$ \\
\hline SRC-15A & $\mathrm{x}$ & $102 \mathrm{~N} 47 \mathrm{~W} 34 \mathrm{CCCC}$ \\
\hline SRC-16 & $\mathrm{x}$ & 102N48W18BBBB2 \\
\hline SRC-17 & $\mathrm{x}$ & 102N48W29AAAD \\
\hline SRC-18B & & 102N48W30ADDD \\
\hline SRC-19 & $\mathrm{x}$ & 102N48W32BCDC \\
\hline SRC-21 & $\mathrm{x}$ & $102 \mathrm{~N} 48 \mathrm{~W} 34 \mathrm{CABA}$ \\
\hline SRC-23 & $\mathrm{x}$ & $102 \mathrm{~N} 48 \mathrm{~W} 35 \mathrm{BBCC}$ \\
\hline SRC-24 & $\mathrm{x}$ & 102N48W36DDAA \\
\hline SRC-26 & $\mathrm{x}$ & 102N49W14CCCC \\
\hline SRC-28 & $\mathrm{x}$ & 102N49W25CCDD2 \\
\hline SRC-31 & $\mathrm{x}$ & 103N50W36DDDD1 \\
\hline SRC-32A & & 102N49W36DCCD2 \\
\hline SRC-33 & & 101N49W 6ADCC \\
\hline SRC-34 & $\mathrm{x}$ & 102N48W34BBBB2 \\
\hline SRC-35A & & $102 \mathrm{~N} 48 \mathrm{~W} 35 \mathrm{ABBB}$ \\
\hline SRC-38A & & $101 \mathrm{~N} 49 \mathrm{~W} 12 \mathrm{AAAA} 2$ \\
\hline SRC-39A & & $101 \mathrm{~N} 48 \mathrm{~W} 5 \mathrm{CCCC} 2$ \\
\hline SRC-42 & & 102N48W17DDDD \\
\hline SRC-43 & & 102N49W24DDDA \\
\hline SRC-45 & & 102N49W23ADAA \\
\hline SRC-46 & & 101N48W13AAAA \\
\hline SRC-48 & & $101 \mathrm{~N} 49 \mathrm{~W} 2 \mathrm{AABA}$ \\
\hline SRC-49 & & 101N48W12AAAA \\
\hline SRC-52 & & 101N48W 3DBCD \\
\hline SRC-53 & & 101N48W 2DCDD \\
\hline SRC-54 & & $101 \mathrm{~N} 47 \mathrm{~W} 6 \mathrm{DAAD}$ \\
\hline
\end{tabular}



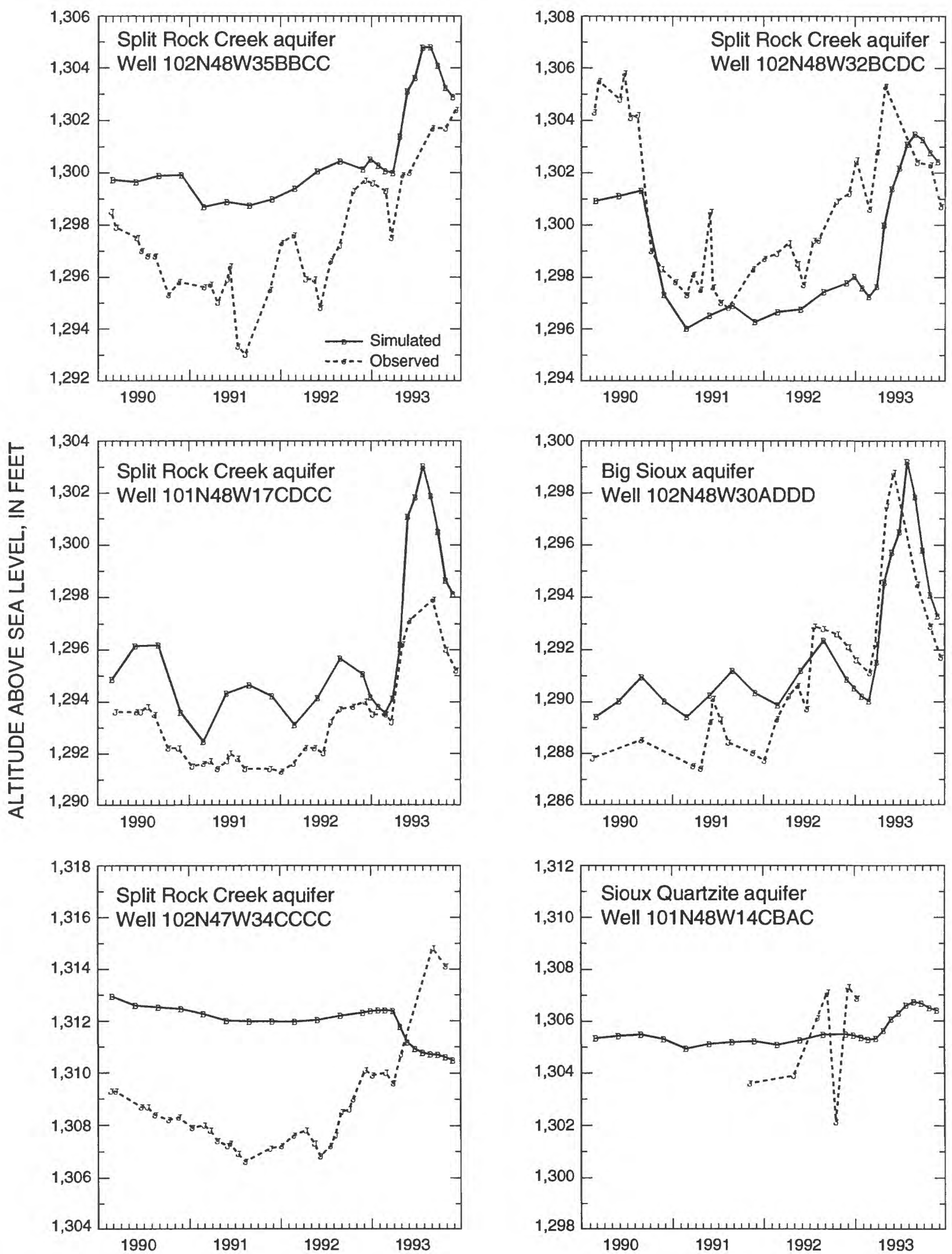

Figure 16. Comparison of simulated and observed hydraulic head in Split Rock Creek, Big Sioux, and Sioux Quarzite aquifers for transient simulations, 1990-93. 
Simulated head for the grid block encompassing well $102 \mathrm{~N} 48 \mathrm{~W} 35 \mathrm{BBCC}$, which is located near the south edge of the area where the Split Rock Creek aquifer is hydraulically connected to the Big Sioux aquifer, follows the measured trends in the Split Rock Creek aquifer. However, the declines in observed head during the summers of 1990 and 1991 were not matched by the model. An explanation could be that averaging the stress over the time periods dampens the effect of specific variations in stresses, which may be reflected in the observed head. Simulated head for wells 102N48W32BCDC and 101N48W17CDCC, which are located where the Split Rock Creek aquifer is hydraulically connected to the Brandon and Big Sioux aquifers, match the trends in measured water levels. Comparison of simulated and measured water levels at well 102N48W30ADDD in the Big Sioux aquifer, which is located on the north edge of the area where the Split Rock Creek aquifer is hydraulically connected to the Big Sioux aquifer, shows that simulated water levels closely match measured values. Simulated heads near areas with hydraulic connections to the alluvial system were in close agreement with the measured water levels. Simulated head for well 102 N47W34CCCC, which is located in the Split Rock Creek aquifer closest to the east boundary, shows little response to stress compared to the measured water levels. Simulated heads closer to the boundaries were less responsive to stresses than measured water levels. The hydrograph of well 101N48W14CBAC in the Sioux Quartzite, located near the south boundary of the Split Rock Creek aquifer and east of the Big Sioux aquifer, shows that simulated heads approximated the measured water levels in a private well in the Sioux Quartzite.

\section{Simulations of Hypothetical Conditions}

Transient simulations of a hypothetical average year divided into quarterly stress periods with seasonal variation in stresses were used to assess the watersupply potential of the Split Rock Creek aquifer. The same sequence of simulations was made with additional pumping stresses divided between layers 2 and 3 and the results were compared. Simulated pumping at the existing Brandon well was increased to $0.9 \mathrm{ft}^{3} / \mathrm{s}$ for all four quarters. The wells on the northeast edge of Sioux Falls were not included in the simulation to analyze the potential of the area south and east of Brandon. Seasonal recharge rates, evapotranspiration, and changes in stream stage were determined for each quarter of the hypothetical average year. Recharge estimates were based on the average (1961-90) precipitation (table 2) with the distribution similar to the calibration simulations. Evapotranspiration and river stage were determined for the respective stress periods based on the data used for the steady-state simulation.

\section{Simulation of Average Conditions with Increased Pumping}

Simulation of hypothetical quarterly average conditions, repeated for 3 years, was compared to three series of simulations of the same conditions, repeated for 3 years except additional pumping of 2, 4, and $6 \mathrm{ft}^{3} / \mathrm{s}$ was added to each simulation. The location of the hypothetical wells (fig. 17) were in the area where the Split Rock Creek aquifer is thickest.

The mean drawdowns (the average head change for all grid blocks in the main body of the Split Rock Creek aquifer) at the end of 3 years of simulation were $8.0 \mathrm{ft}$ with additional pumping of $2.0 \mathrm{ft}^{3} / \mathrm{s}, 13.0 \mathrm{ft}$ with additional pumping of $4 \mathrm{ft}^{3} / \mathrm{s}$, and $32.5 \mathrm{ft}$ with additional pumping of $6 \mathrm{ft}^{3} / \mathrm{s}$. Thirty grid blocks, which represent the Brandon aquifer in the area where a hydraulic connection to the Split Rock Creek aquifer exists, went dry in the simulation with additional pumping of $6 \mathrm{ft}^{3} / \mathrm{s}$. Comparison of the mean drawdown at the end of each quarter for the simulation series with pumping of $4 \mathrm{ft}^{3} / \mathrm{s}$ (table 7) shows the mean hydraulic head reaching a new equilibrium condition during the third year. The mean drawdown at the end of the second year was $12.7 \mathrm{ft}$, and at the end of the third year was $13.0 \mathrm{ft}$.

Table 7. Mean drawdown in the main body of the Split Rock aquifer with additional pumping of 4 cubic feet per second

[Value is the mean difference in the simulated transient quarterly hydraulic head in the main body of the Split Rock Creek aquifer with repeated transient quarterly simulation of a hypothetical average year versus the hypothetical average year with additional pumping of 4 cubic feet per second]

\begin{tabular}{lcccc}
\hline $\begin{array}{c}\text { Simulation } \\
\text { year }\end{array}$ & $\begin{array}{c}\text { December } \\
\text { through } \\
\text { February } \\
\text { (feet) }\end{array}$ & $\begin{array}{c}\text { March } \\
\text { through } \\
\text { May } \\
\text { (feet) }\end{array}$ & $\begin{array}{c}\text { June } \\
\text { through } \\
\text { August } \\
\text { (feet) }\end{array}$ & $\begin{array}{c}\text { September } \\
\text { through } \\
\text { November } \\
\text { (feet) }\end{array}$ \\
\hline 1st year & 7.9 & 10.2 & 11.1 & 11.6 \\
2nd year & 12.2 & 12.5 & 12.6 & 12.7 \\
3rd year & 12.9 & 13.0 & 13.0 & 13.0 \\
\hline
\end{tabular}




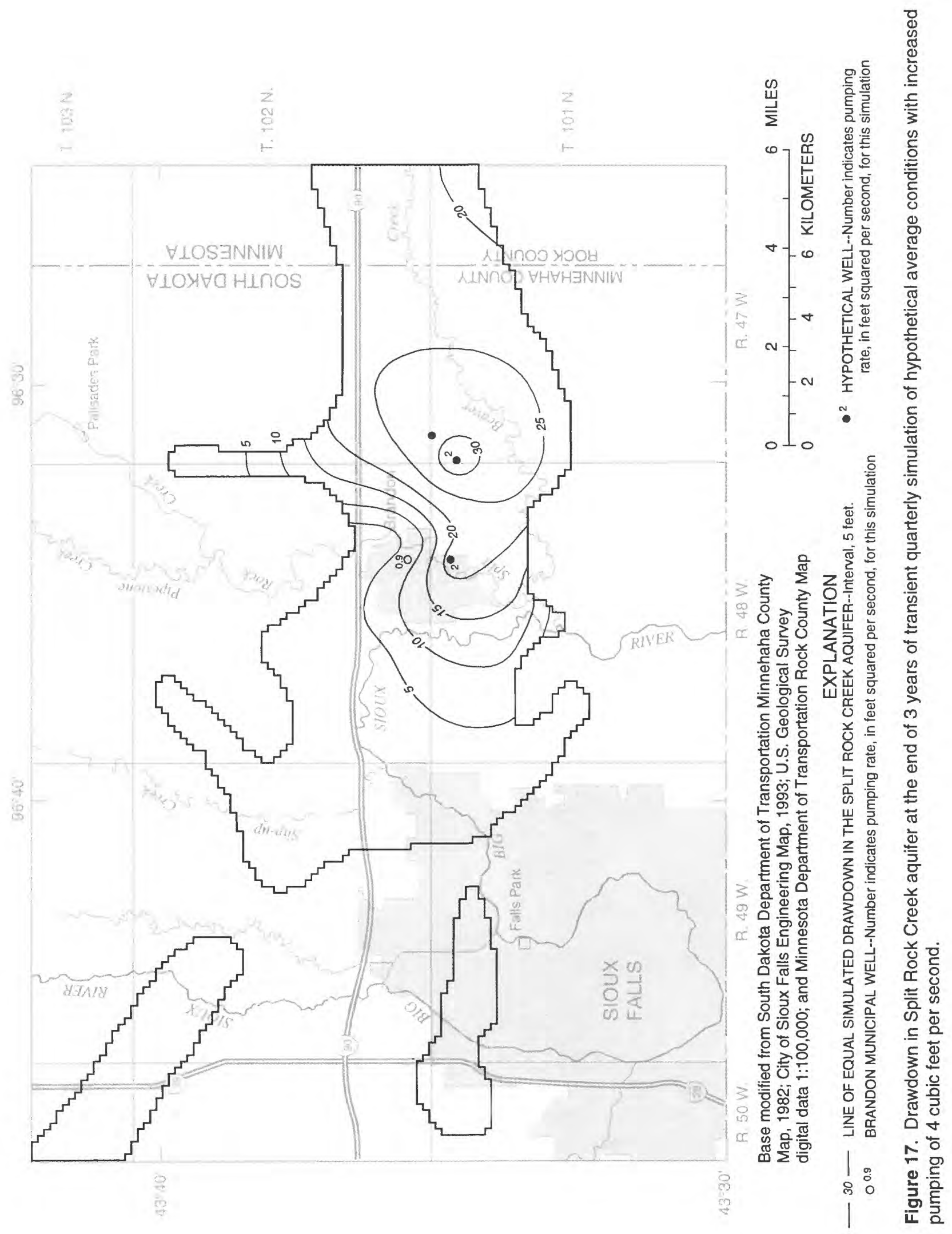


Table 8. Comparison of the simulated water budget for the main body of the Split Rock Creek aquifer of hypothetical average conditions to hypothetical average conditions with additional pumping of 4 cubic feet per second

$\left[\mathrm{ft}^{3} / \mathrm{s}\right.$, cubic feet per second. Value is the water budget component for September through November of third year of transient quarterly simulation of hypothetical average conditions versus hypothetical average conditions with additional pumping of $\left.4 \mathrm{ft}^{3} / \mathrm{s}\right]$

\begin{tabular}{|c|c|c|c|}
\hline Budget component & $\begin{array}{l}\text { Hypothetical average } \\
\text { conditions }\end{array}$ & $\begin{array}{l}\text { Hypothetical average } \\
\text { conditions with additional } \\
\text { pumping of } 4 \mathrm{ft}^{3} / \mathrm{s}\end{array}$ & $\begin{array}{l}\text { Difference in water } \\
\text { budgets }\end{array}$ \\
\hline \multicolumn{4}{|c|}{ Inflow $\left(\mathrm{ft}^{3} / \mathrm{s}\right)$} \\
\hline Recharge from Sioux Quartzite aquifer ${ }^{1}$ & 1.8 & 2.6 & 0.8 \\
\hline Recharge from specified-flow boundaries & .3 & .3 & .0 \\
\hline Recharge from Big Sioux aquifer & .0 & .0 & .0 \\
\hline Recharge from Brandon aquifer & .4 & 3.0 & 2.6 \\
\hline Total inflow & 2.5 & 5.9 & 3.4 \\
\hline \multicolumn{4}{|c|}{ Outflow $\left(\mathbf{f t}^{3} / \mathrm{s}\right)$} \\
\hline Discharge to Sioux Quartzite aquifer ${ }^{1,2}$ & -.9 & -.6 & -.3 \\
\hline Discharge to wells & -.9 & -4.9 & 4.0 \\
\hline Discharge to Big Sioux aquifer & -.5 & -.4 & -.1 \\
\hline Discharge to Brandon aquifer & -.2 & -.0 & -.2 \\
\hline Total outflow & -2.5 & -5.9 & 3.4 \\
\hline
\end{tabular}

\footnotetext{
${ }^{1}$ The discontinuous parts of the Split Rock Creek aquifer to the west and northwest are included in the Sioux Quartzite aquifer budget.

${ }^{2}$ This budget component also includes horizontal flow which could occur directly from the Split Rock Creek aquifer to the Big Sioux aquifer through lenses of the Split Rock Creek Formation overlying the Sioux Quartzite near the south boundary of the Split Rock Creek aquifer.
}

A map of simulated drawdown with added pumping of $4 \mathrm{ft}^{3} / \mathrm{s}$ at two wells (fig. 17) shows an area of approximately $20 \mathrm{mi}^{2}$ with a drawdown greater than $20 \mathrm{ft}$. The smaller drawdown in the area north of Brandon was the result of inflow induced from the Brandon aquifer along the flood plain of Split Rock Creek. The differences in the water budget at the end of the fourth quarter of the third year compared to the water budget with additional pumping of $4 \mathrm{ft}^{3} / \mathrm{s}$ (table 8) show that induced recharge was $2.6 \mathrm{ft}^{3} / \mathrm{s}$ from the alluvial aquifers and about $0.8 \mathrm{ft}^{3} / \mathrm{s}$ from the Sioux Quartzite aquifer.

\section{Simulation of Average Conditions with Seasonal Pumping}

Simulation of hypothetical average conditions with seasonal pumping was used to assess an alternative use of the Split Rock Creek aquifer to meet peak water demands. Simulation of quarterly average conditions, repeated for 3 years, was compared to simulation of quarterly average conditions with increased pumping of $10 \mathrm{ft}^{3} / \mathrm{s}$ for the June through August (summer) quarter and no additional pumping for the remaining quarters. Five hypothetical wells withdrawing $2 \mathrm{ft}^{3} / \mathrm{s}$ each (fig. 18) were located in the area where the Split Rock Creek aquifer is thickest.
The mean drawdown in the main body of the Split Rock Creek aquifer at the end of summer quarter after 3 years of simulation with additional pumping of $10 \mathrm{ft}^{3} / \mathrm{s}$ was $30.1 \mathrm{ft}$. Comparison of the mean drawdown at the end of each quarter for the simulation series (table 9) shows the decline in hydraulic head approaching a new seasonal equilibrium condition during the third year. The mean drawdown at the end of the second year was $10.9 \mathrm{ft}$, and at the end of the third year was $11.1 \mathrm{ft}$.

Table 9. Mean drawdown in the main body of the Split Rock Creek aquifer with additional pumping during June through August quarter of 10 cubic feet per second

[Value is the mean difference in hydraulic head in the Split Rock Creek aquifer with repeated transient quarterly simulation of a hypothetical average year versus a hypothetical average year with additional pumping withdrawal of 10 cubic feet per second during June through August quarter]

\begin{tabular}{lcrcc}
\hline $\begin{array}{c}\text { Simulation } \\
\text { year }\end{array}$ & $\begin{array}{c}\text { December } \\
\text { through } \\
\text { February } \\
\text { (feet) }\end{array}$ & $\begin{array}{c}\text { March } \\
\text { through } \\
\text { May } \\
\text { (feet) }\end{array}$ & $\begin{array}{c}\text { June } \\
\text { through } \\
\text { August } \\
\text { (feet) }\end{array}$ & $\begin{array}{c}\text { September } \\
\text { through } \\
\text { November } \\
\text { (feet) }\end{array}$ \\
\hline 1st year & 0.0 & 0.0 & 28.3 & 10.1 \\
2nd year & 5.9 & 4.4 & 29.9 & 10.9 \\
3rd year & 6.3 & 4.6 & 30.1 & 11.1 \\
\hline
\end{tabular}




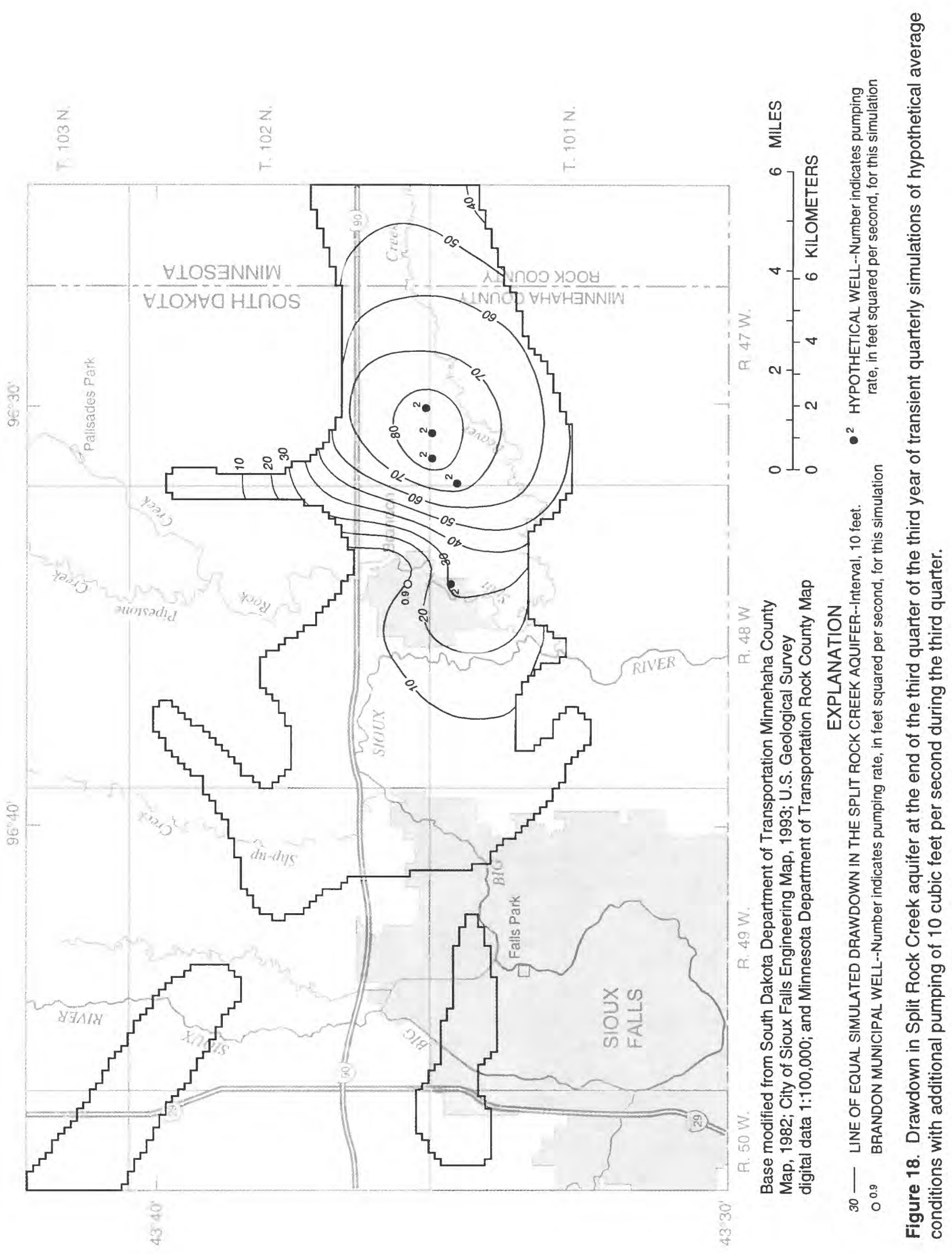


The simulated mean heads at the end of the spring quarter of the third year at the grid blocks where the Brandon aquifer is hydraulically connected to the Split Rock Creek aquifer showed a downward gradient of $0.3 \mathrm{ft}$ compared to an upward gradient of $0.3 \mathrm{ft}$ in the steady-state simulation.

The drawdown with added pumping of $10.0 \mathrm{ft}^{3} / \mathrm{s}$ during the summer quarter (fig. 18) shows an area of approximately $33 \mathrm{mi}^{2}$ with a drawdown greater than $20 \mathrm{ft}$ at the end of the summer quarter of the third year. Although the drawdowns are substantial, the simulated head remained above the top of the aquifer at each grid block in the area with drawdown greater than $20 \mathrm{ft}$.

Hydrologic models have limitations due to the approximations of hydrologic parameters. Model calibration refines estimates; however, the input data set for the calibration solution is not unique and other combinations of parameters could produce similar results. Properties that are significant in assessment of the Split Rock Creek aquifer as a water supply are boundary conditions where the Split Rock Creek aquifer continues into Minnesota, transmissivity of the Sioux Quartzite aquifer, and vertical conductance between the alluvial aquifers and the Split Rock Creek aquifer. To evaluate this uncertainty, additional simulations were made.

Substantial declines in head are indicated to extend into Minnesota during the quarter when the pumping rate was $10 \mathrm{ft}^{3} / \mathrm{s}$. The specified flow at the east edge of model assumes that induced inflow at the boundary would be limited to the flow calculated during the steady-state simulation. Additional inflow could be induced, depending on the extent and hydraulic properties of the Split Rock Creek aquifer east of the model area. An alternative simulation to evaluate the induced inflow was made with the east boundary changed to a constant-head boundary as used in the steady-state simulation. The mean drawdown in the Split Rock Creek aquifer at the end of the summer quarter after 3 years of hypothetical simulation with constant-head boundaries on the east side of model and additional pumping of $10.0 \mathrm{ft}^{3} / \mathrm{s}$ during the summer quarter was $23.8 \mathrm{ft}$. The area with drawdown greater than $20 \mathrm{ft}$ at the end of the summer quarter of the third year with additional pumping of $10.0 \mathrm{ft}^{3} / \mathrm{s}$ was $29 \mathrm{mi}^{2}$ compared to $33 \mathrm{mi}^{2}$ with the specified-flow boundary. The induced inflow from the continuation of the Split Rock Creek aquifer in Minnesota was $1.7 \mathrm{ft}^{3} / \mathrm{s}$.

Two additional series of simulations were made to evaluate the effect of uncertainty in hydraulic properties of the Sioux Quartzite and the fractured siltstone. A simulation series was made of seasonal pumping with the transmissivity of the Sioux Quartzite doubled, to a mean value of $320 \mathrm{ft}^{2} / \mathrm{d}$ for layer 2 and $120 \mathrm{ft}^{2} / \mathrm{d}$ for layer 3 , and the vertical conductance of the fractured siltstone doubled, to a mean value of $0.004(\mathrm{ft} / \mathrm{d}) / \mathrm{ft}$. A similar simulation of seasonal pumping was made with the transmissivity of the Sioux Quartzite halved, to a mean value of $80 \mathrm{ft}^{2} / \mathrm{d}$ for layer 2 and $30 \mathrm{ft}^{2} / \mathrm{d}$ for layer 3 , and the vertical conductance of the fractured siltstone halved, to a mean value of $0.001(\mathrm{ft} / \mathrm{d}) / \mathrm{ft}$. A graphical comparison of simulated seasonal drawdown in the Split Rock Creek aquifer (fig. 19) shows the maximum mean drawdown varying approximately $10 \mathrm{ft}$. The change in the maximum mean drawdown between the second and third year of the respective simulation series remained small. Recovery from seasonal pumping withdrawal would not be complete in one season; however, a new equilibrium condition was simulated, with induced recharge and lower hydraulic heads. In the series with the higher transmissivity and vertical conductance, the mean head in the main body of the Split Rock Creek aquifer recovered to within $2.5 \mathrm{ft}$ of simulated average conditions during the spring quarter of the third year. The difference in simulated mean heads at the grid blocks where the Brandon aquifer is hydraulically connected to the Split Rock Creek aquifer showed a downward gradient of $0.1 \mathrm{ft}$ compared to an upward gradient of $0.3 \mathrm{ft}$ in the steady-state simulation. Thus, recovery beyond this point would be slower because induced recharge from the Brandon aquifer would cease and the Split Rock Creek aquifer again would discharge to the Brandon aquifer.

\section{SUMMARY}

This report describes the hydrogeology of the Split Rock Creek aquifer in southeast Minnehaha County, South Dakota. A three-dimensional groundwater flow model was calibrated and used as a tool to preliminarily assess the water-supply potential of the Split Rock Creek aquifer. The aquifer consists of rounded quartzite sand derived from the preCretaceous weathering of the exposed Sioux Quartzite deposited in an embayment in the irregular Sioux Quartzite surface. The lithology fines upward through a sequence of siltstones and claystones. These bedrock units are overlain by glacial deposits and alluvial aquifers. 


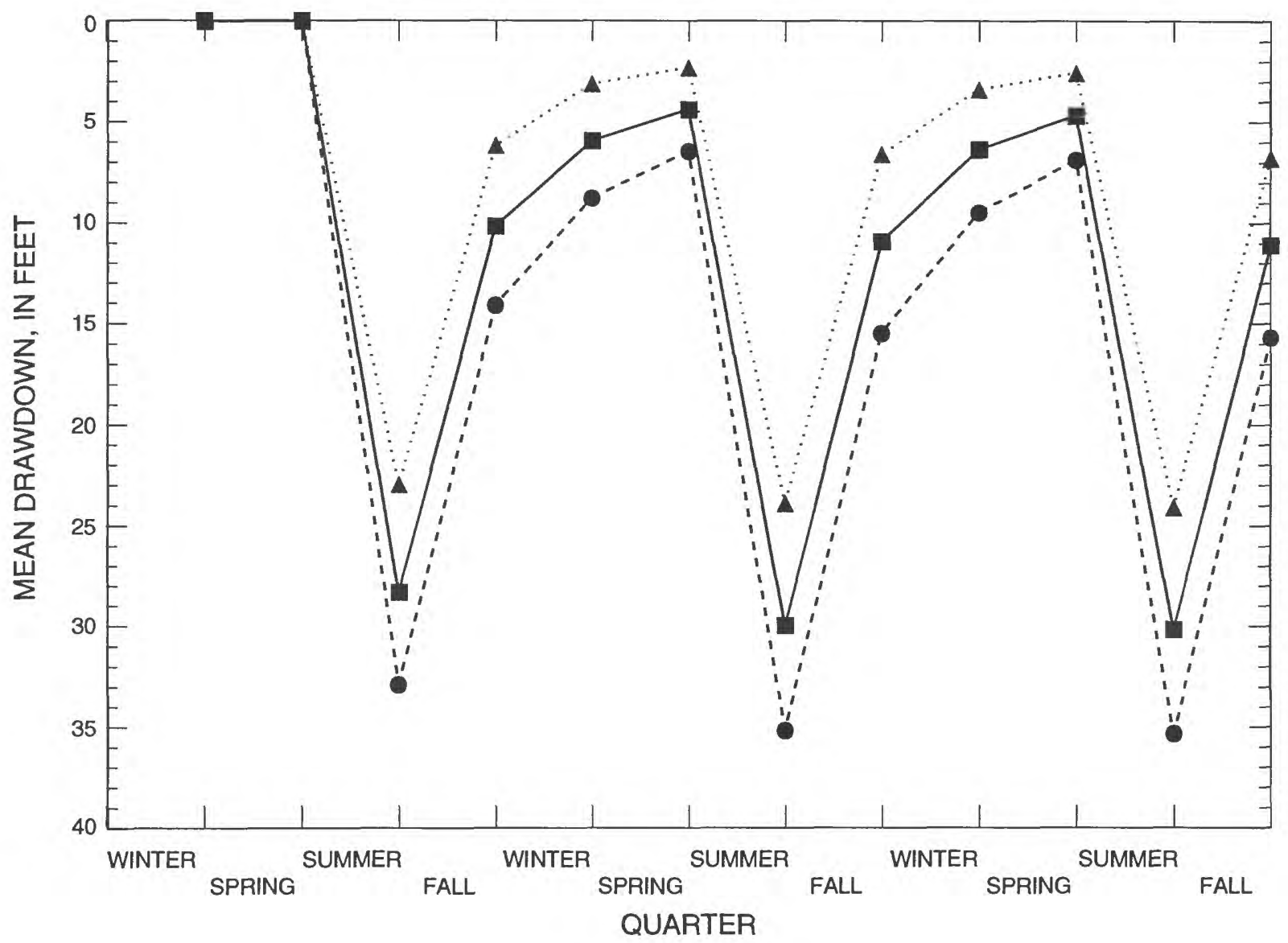

\section{EXPLANATION}

MEAN SIMULATED DRAWDOWN IN SPLIT ROCK CREEK AQUIFER WITH SIOUX QUARTZITE TRANSMISSIVITY DOUBLED (MEAN VALUE INCREASED FROM 160 FEET SQUARED PER DAY TO 320 FEET SQUARED PER DAY FOR LAYER 2, 60 FEET SQUARED PER DAY TO 120 FEET SQUARED PER DAY FOR LAYER 3) AND FRACTURED SILTSTONE VERTICAL CONDUCTANCE DOUBLED (MEAN VALUE INCREASED FROM 0.002 FOOT PER DAY TO 0.004 FOOT PER DAY)

MEAN SIMULATED DRAWDOWN IN SPLIT ROCK CREEK AQUIFER WITH CALIBRATED VALUES FOR SIOUX QUARTZITE TRANSMISSIVITY AND FRACTURED SILTSTONE CONDUCTANCE

- - MEAN SIMULATED DRAWDOWN IN SPLIT ROCK CREEK AQUIFER WITH SIOUX QUARTZITE TRANSMISSIVITY HALVED (MEAN VALUE INCREASED FROM 160 FEET SQUARED PER DAY TO 80 FEET SQUARED PER DAY FOR LAYER 2, 60 FEET SQUARED PER DAY TO 30 FEET SQUARED PER DAY FOR LAYER 3) AND FRACTURED SILTSTONE VERTICAL CONDUCTANCE HALVED (MEAN VALUE INCREASED FROM 0.002 FOOT PER DAY TO 0.001 FOOT PER DAY)

Figure 19. Comparison of mean drawdown in the main body of the Split Rock Creek aquifer with transient quarterly simulation of hypothetical average conditions and additional pumping of 10 cubic feet per second during the summer quarter, with increased and decreased Sioux Quartzite transmissivity and fractured siltstone vertical conductance. 
Recharge to the Split Rock Creek aquifer is from infiltration of precipitation to the Sioux Quartzite at outcrops or areas overlain by permeable sediments and movement through the joints and fractures. Discharge occurs vertically to overlying alluvium where the intervening layers are fractured siltstone and horizontally to the Sioux Quartzite or permeable deposits overlying areas of the Sioux Quartzite. Hydrographs of hydraulic head in the Split Rock Creek aquifer and overlying alluvial aquifers show similar response to changes in aquifer stresses where the intervening layers are fractured siltstone.

The ground-water system was simulated with a numerical flow model with three aquifer layers. The upper layer simulated the alluvial aquifers; the second and third layers each simulated parts of the Split Rock Creek aquifer and the surrounding Sioux Quartzite aquifer. The confining unit between layer 1 and layer 2 simulated areas with vertical flow through fractured siltstones. The study area was divided into grid blocks $660 \mathrm{ft}$ on a side with 112 rows and 160 columns. Combinations of constant-head, specified-flow, and no-flow boundaries were used to best represent boundary conditions.

Hydraulic conductivity assigned to alluvial aquifers ranged from 200 to $300 \mathrm{ft} / \mathrm{d}$. The transmissivity assigned to the Split Rock Creek aquifer ranged from 200 to $12,700 \mathrm{ft}^{2} / \mathrm{d}$ with a mean of $2,100 \mathrm{ft}^{2} / \mathrm{d}$. Transmissivity was divided between layer 2 and layer 3 in the thickest part of the Split Rock Creek aquifer with layer 3 representing the part of the Split Rock Creek aquifer below an altitude of $1,100 \mathrm{ft}$. The mean transmissivity used to represent the Sioux Quartzite aquifer was $160 \mathrm{ft}^{2} / \mathrm{d}$ in layer 2 and $60 \mathrm{ft}^{2} / \mathrm{d}$ in layer 3. The storage coefficient assigned to the Split Rock Creek aquifer was 0.00026 , and that assigned to the Sioux Quartzite aquifer was 0.0001 . A specific yield of 0.2 was used as the storage coefficient for water-table conditions. The range of vertical conductance assigned to the fractured siltstone separating the Split Rock Creek aquifer from the overlying alluvial aquifers ranged from 0.00002 to $0.006(\mathrm{ft} / \mathrm{d}) / \mathrm{ft}$ with a mean of $0.002(\mathrm{ft} / \mathrm{d}) / \mathrm{ft}$. A vertical hydraulic conductivity of $0.05 \mathrm{ft} / \mathrm{d}$ for streambeds was used in calculating flow to and from streams.

The period from 1985-89 was prior to significant pumping from the Split Rock Creek aquifer and, when averaged, was considered representative of steady state. Estimated average 1985-89 recharge to the alluvial aquifers was $5.0 \mathrm{in} / \mathrm{yr}$. Estimated recharge to the Sioux Quartzite aquifer at outcrops and areas overlain by permeable sediments averaged $3.0 \mathrm{in} / \mathrm{yr}$. An empirical multiplication factor based on seasonal changes in soil conditions and moisture utilized for plant growth was used to calculate the seasonal recharge rate. The potential evapotranspiration rate from the alluvial aquifers was 36 in/yr decreasing with the depth of the water table below the land surface. The combined average pumping rate from the Big Sioux and Brandon aquifers during the steady-state simulation was $0.4 \mathrm{ft}^{3} / \mathrm{s}$. Transient simulations included pumping from the Split Rock Creek aquifer which began in 1990 at a rate ranging from 0.4 to $0.7 \mathrm{ft}^{3} / \mathrm{s}$ per well at three production wells.

Steady-state simulation, transient quarterly simulation for 1990-92, and transient monthly simulation for 1993 were used to calibrate the model to observed hydraulic heads. The average of the difference between the simulated and observed hydraulic heads at 23 wells was $-0.4 \mathrm{ft}$ with an average absolute difference of $2.2 \mathrm{ft}$ for the steady-state simulation. The water budget for the Split Rock Creek aquifer for steady-state simulation showed inflow of $1.8 \mathrm{ft}^{3} / \mathrm{s}$ to the main body of the Split Rock Creek aquifer from hydraulic connection to the Sioux Quartzite aquifer and $0.3 \mathrm{ft}^{3} / \mathrm{s}$ from constant-head boundaries. Vertical outflow of $0.6 \mathrm{ft}^{3} / \mathrm{s}$ to the Big Sioux aquifer and $0.6 \mathrm{ft}^{3} / \mathrm{s}$ to the Brandon aquifer occurred through the fractured siltstone. Horizontal outflow of $0.9 \mathrm{ft}^{3} / \mathrm{s}$ occurred along the southcentral boundary of the Split Rock Creek aquifer to the Sioux Quartzite and through shallow permeable lenses of the Split Rock Creek Formation connected to the Big Sioux aquifer. A sensitivity analysis of the steady-state model showed that changes in recharge to the Sioux Quartzite aquifer, vertical conductance between Split Rock Creek aquifer and the alluvial aquifers, and transmissivity of the Split Rock Creek aquifer had the largest effect on simulated hydraulic heads.

Twelve transient quarterly simulations included a period with below-normal precipitation in 1990 and above-normal precipitation during 1991-92. Precipitation during the 12 transient monthly simulations for 1993 was 12 in. above normal. The average difference between simulated and observed hydraulic heads was $+2.7 \mathrm{ft}$ for the quarterly transient simulations and $+0.4 \mathrm{ft}$ for the monthly transient simulations. Analysis of distribution of difference between simulated and observed hydraulic heads showed a large part of the deviation occurred in wells near the boundaries in the 
arms with a closer fit accomplished in the main body of the Split Rock Creek aquifer.

Transient simulations of a hypothetical average year divided into quarterly stress periods with seasonal variation in stresses were used to assess the watersupply potential of the Split Rock Creek aquifer. The same sequence of simulations was made with additional pumping stresses and the results compared. Simulation of hypothetical quarterly average conditions, repeated for 3 years, was compared to three series of simulations of the same conditions, repeated for 3 years, except additional pumping of 2, 4, and $6 \mathrm{ft}^{3} / \mathrm{s}$ was added to each simulation. The drawdown in potentiometric head with additional pumping of $4.0 \mathrm{ft}^{3} / \mathrm{s}$ showed an area of approximately $20 \mathrm{mi}^{2}$ with a drawdown greater than $20 \mathrm{ft}$. A new equilibrium was reached by induced recharge of $0.8 \mathrm{ft}^{3} / \mathrm{s}$ from the Sioux Quartzite aquifer and $2.6 \mathrm{ft}^{3} / \mathrm{s}$ from the alluvial aquifers. The drawdown in hydraulic head with additional pumping of $6.0 \mathrm{ft}^{3} / \mathrm{s}$ caused thirty grid blocks in the Brandon aquifer with hydraulic connection to the Split Rock Creek aquifer to go dry. Similar simulations of average conditions with seasonal pumping of $10.0 \mathrm{ft}^{3} / \mathrm{s}$ during the summer quarter was used to assess an alternative use of the Split Rock Creek aquifer to meet peak water demands. The results indicated partial recovery from pumping stress would occur. The drawdown in hydraulic head with added pumping of $10.0 \mathrm{ft}^{3} / \mathrm{s}$ showed an area of approximately $33 \mathrm{mi}^{2}$ with a drawdown greater than $20 \mathrm{ft}$ at the end of the summer quarter of the third year. The simulated mean hydraulic head at the end of the spring quarter of the third year at the grid blocks where the Brandon aquifer is hydraulically connected to the Split Rock Creek aquifer showed a downward gradient of $0.3 \mathrm{ft}$ compared to an upward gradient of $0.3 \mathrm{ft}$ in the steady-state simulation.

Additional simulations were made to evaluate uncertainty in assigning hydrologic parameters. Changing the specified-flow boundary on the east side of the Split Rock Creek aquifer to a constant-head boundary increased induced recharge by $1.7 \mathrm{ft}^{3} / \mathrm{s}$.

\section{REFERENCES}

Anderson, H.W. Jr., 1986, Hydrologic and water-quality characteristics of crystalline-rock aquifers of Archean and Proterozoic age, Minnesota: U.S. Geological Survey Water-Resources Investigations Report 86-4003, 3 pl.
Anderson, H.W. Jr., Broussard, W.L., Farrell, D.F., and Felsheim, P.E., 1976, Water resources of the Rock River watershed, southwestern Minnesota: U.S. Geological Survey Hydrologic Investigation Atlas HA-555, 3 sheets.

Bretz, R.F., 1981, Geology of the Sioux Falls, South Dakota area in Cretaceous stratigraphy and sedimentation in northwest Iowa, northeast Nebraska, and southeast South Dakota: Iowa Geological Survey Guidebook Series 4, p. 129-147.

Burkart, M.R., 1984, Availability and quality of water from the Dakota aquifer, northwest Iowa: U.S. Geological Survey Water-Supply Paper 2215, 65 p., 8 pl.

Chandler, V.W., 1994, Gravity investigation for potential ground-water resources in Rock County, Minnesota: Minnesota Geological Survey Report of Investigations 44, $24 \mathrm{p}$.

Farnsworth, R.K., and Thompson, E.S., 1982, Mean monthly, seasonal, and annual pan evaporation for the United States: National Oceanic and Atmospheric Administration Technical Report NWS 34, 82 p.

Hantush, M.S., and Jacob, C.E., 1955, Nonsteady radial flow in an infinite leaky aquifer: American Geophysical Union Transactions, v. 36, no. 1, p. 95-100.

Hansen, D.S., 1988, Appraisal of the water resources of the Big Sioux aquifer, Moody County, South Dakota: U.S. Geological Survey Water-Resources Investigations Report 87-4057, 38 p.

Jorgensen, D.G., and Ackroyd, E.A., 1973, Water resources of the Big Sioux River valley near Sioux Falls, South Dakota: U.S. Geological Survey Water-Supply Paper 2024, 50 p., 1 pl.

Kanivetsky, R., and Walton, M., 1986, Hydrologic map of Minnesota, bedrock hydrogeology: A discussion to accompany Minnesota State Map Series S-2, in Anderson, H.W., Hydrologic and water-quality characteristics of crystalline-rock aquifers of Archean and Proterozoic age, Minnesota: U.S. Geological Survey Water-Resources Investigations Report 86-4003, 11 p.

Lindgren, R.J., and Niehus, C.A., 1992, Water resources of Minnehaha County, South Dakota: U.S. Geological Survey Water-Resources Investigations Report 91-4101, 80 p.

Ludvigson, G.A., McKay, R.M., Iles, D., Bretz, R.F., 1981, Lithostratigraphy and sedimentary petrology of the Split Rock Creek Formation, Late Cretaceous, of southeastern South Dakota, in Cretaceous stratigraphy and sedimentation in northwest Iowa, northeast Nebraska, and southeast South Dakota: Iowa Geological Survey Guidebook Series 4, p. 77-82.

McDonald, M.G., and Harbaugh, A.W., 1988, A modular three-dimensional finite-difference ground-water flow model: U.S. Geological Survey Techniques of WaterResources Investigations, book 6, chap. A1, 574 p. 
National Oceanic and Atmospheric Administration, 1993,

Climatological data, annual summary, South Dakota, 1993: v. 98, no. 13.

Ohland, G. L., 1990, Appraisal of the water resources of the Skunk Creek aquifer in Minnehaha County, South Dakota: U.S. Geological Survey Water-Resources Investigations Report 87-4156, 54 p.

Orzol, L.L., and McGrath, T.S., 1992, Modifications of the U.S. Geological Survey modular, finite-difference, ground-water flow model to read and write geographic information system files: U.S. Geological Survey Open-File Report 92-50, 200 p.
Pence, S.F., 1996, Hydrogeology and recharge of the Split Rock Creek aquifer, southeastern South Dakota: Grand Forks, University of North Dakota, M.S. thesis, 150 p.

Rothrock, E.P., 1958, Geology and water supplies in the vicinity of the pathfinder steam power plant project in Minnehaha County, South Dakota: Minneapolis, Minnesota, Technical Report prepared for Northern States Power Company, 37 p.

Tomhave, D.W., 1994, Geology of Minnehaha County, South Dakota: South Dakota Geological Survey Bulletin 37, 53 p., 4 pl.

U.S. Department of Commerce, 1985-93, Climatological data for South Dakota (issued annually). 